Review Article

\title{
Carica papaya L. Leaf: A Systematic Scoping Review on Biological Safety and Herb-Drug Interactions
}

\author{
X. Y. Lim (i), J. S. W. Chan $(D)$, N. Japri $(D$, J. C. Lee $(D)$, and T. Y. C. Tan $(1)$ \\ Herbal Medicine Research Centre, Institute for Medical Research, National Institutes of Health, Ministry of Health Malaysia, \\ Setia Alam 40170, Shah Alam, Malaysia \\ Correspondence should be addressed to X. Y. Lim; limxy@moh.gov.my
}

Received 9 February 2021; Accepted 22 April 2021; Published 7 May 2021

Academic Editor: Hicham Harhar

Copyright (c) 2021 X. Y. Lim et al. This is an open access article distributed under the Creative Commons Attribution License, which permits unrestricted use, distribution, and reproduction in any medium, provided the original work is properly cited.

Introduction. The Carica papaya L. leaf is gaining interest as a potential therapeutic agent for alleviating dengue- and non-dengueassociated thrombocytopaenia. In that regard, safety considerations are as important as efficacy potential. The safety evaluation of botanical products for human use is complicated by variable formulations, complex phytochemical composition, and extrinsic toxicants. This review aimed to systematically collate related safety clinical and preclinical data, as well as reports on herb-drug interactions of C. papaya leaf consumption. Methods. A systematic search using predetermined keywords on electronic databases (MEDLINE, Cochrane Library Central, LILACS, and Web of Science) and grey literature was conducted. Relevant clinical and preclinical studies were identified, screened, and analysed to present an overall safety profile of C. papaya leaf consumption. Results. A total of 41 articles were included (23 clinical, 5 ongoing trials, and 13 preclinical) for descriptive analysis on study characteristics, adverse reactions, toxicity findings, and herb-drug interactions, from which 13 randomised controlled and quasiexperimental trials were further assessed for risk of bias and reporting quality. Overall, C. papaya leaf consumption (in the form of juice and standardised aqueous extract) was well tolerated by adult humans for short durations ( $<$ five days) while one randomised controlled trial reported safe consumption of C. papaya leaf standardised aqueous extract in children (aged 1-12 years). Minor gastrointestinal side effects were most commonly reported. There are concerns about hepatotoxicity and reproductive toxicity in long-term use, supported by animal studies. Unfavourable herb-drug interactions with metformin, glimepiride, digoxin, ciprofloxacin, and artemisinin were accounted. Conclusion. C. papaya leaf consumption in adults is generally safe for short-term use though cautioned in pregnancy and people with liver impairment. It has potential herb-drug interactions with oral hypoglycaemic agents, p-glycoprotein substrates, and antibiotics with cation chelating properties.

\section{Introduction}

Carica papaya L. is a common medicinal plant used in folk medicine [1]. Traditionally, the leaves of C. papaya, in decoction or infusion form, are consumed orally to reduce blood pressure and sugar levels. The juice of C. papaya leaf is used for irregular menstruation while infusion of young leaf is used for fever $[2,3]$. There is long standing interest in the use of C. papaya leaf as an adjunctive treatment to the standard care for improving platelet counts, especially in cases of dengue fever [4], or more recently, in cancer treatments [5]. Among the most important clinical findings on the efficacy of $C$. papaya leaf is its use in thrombocytopaenia management during dengue infection [6], a common and potentially life-threatening complication during the course of infection [7]. Such clinical benefits and potential mechanisms of action have also been investigated and backed by preclinical data [8-10]. Other efficacy evidence of C. papaya leaf includes hypoglycaemic [11], hypolipidaemic [12], gastroprotective [13], antimicrobial [14], antimalarial [15], and wound healing properties [16]. C. papaya leaf has been reported to contain several important phytochemical compounds including flavonoids, alkaloids, tannins, quinones, and steroids which may collectively contribute towards its biological activities $[17,18]$. In addition to the abundance of phenolic compounds with antioxidant properties identified in a methanol extract of C. papaya leaf [19], the alkaloid carpaine was reported to be a 
major contributor towards the leaf's antithrombocytopaenic properties [20].

Apart from being efficacious, the safety assurance of a medicinal herb and its formulation are important considerations. The World Health Organization (WHO) Global Report on Traditional and Complementary Medicine (2019) outlined that the safety of herbal medicines is often required to be assessed thoroughly, in most countries, under processes similar to those for conventional medicine, including postmarketing surveillances [21]. Herbal medicines for traditional use are also subjected to specialised regulatory requirements taking into consideration documented scientific research on similar products that are already marketed [21]. In general, the toxicity of herbs is broadly categorised as intrinsic or extrinsic. Intrinsic toxicity takes into account adverse reactions inherent to the pharmacological nature and bioactive phytochemicals of herbs, while extrinsic toxicity refers to impurities and potential toxicants introduced externally through agricultural practices or processing, for example, heavy-metal and pesticide contamination [22]. General and specific animal toxicity studies of various durations conducted with adherence to Good Laboratory Practice are often required by regulatory agencies when registering a herbal formulation for medicinal use [21]. Herb-drug interaction studies, though challenging to conduct and interpret, are also crucial components of a herb's safety profile [23].

As C. papaya leaf consumption increasingly gains attention for therapeutic uses, it is important to thoroughly assess its safety data, including potential herb-drug interactions. At present, there are still insufficient focused-systematic collection and in-depth analysis on all available safety and toxicity data pertaining to consumption of $C$. papaya leaf. Two systematic reviews on the clinical efficacy and safety of C. papaya leaf were published separately in 2016 and 2019. However, those two reviews were more focused on the metaanalysis of efficacy, accounting for the use of $C$. papaya leaf in dengue patients only. Furthermore, only reported adverse effects during the trials' duration were taken into consideration $[24,25]$. Therefore, this review aimed to systematically search, identify, and collate all safety-related clinical data and animal toxicity studies, as well as reports on herb-drug interactions of orally administered of C. papaya leaf. Based on the findings of two previously published systematic reviews $[24,25]$, it was also observed that diverse formulations of C. papaya leaf were investigated. Hence, the construction of a well-rounded safety profile of $C$. papaya leaf, through the methodological framework of a scoping study to account for the variety of data and flexible information sources, is most suited here. To the best of our knowledge, this is one of the few available systematically conducted comprehensive reviews on clinical safety, toxicity, and herb-drug interactions of C. papaya leaf consumption accounting for both published articles and grey literature.

\section{Materials and Methods}

This review was conducted according to the York Framework of scoping studies by Arskey and O'Malley [26], advanced by Levac et al. [27]. This framework serves as a guide for a standardised and systematic approach in conducting scoping studies to address new or broad research questions of complex or heterogeneous nature. As the safety profile of $C$. papaya leaf encompasses heterogeneous clinical and preclinical evidence, including data on herb-drug interactions, this methodological framework is suited to be applied. All five stages of scoping review, namely, (1) identification of research question (s), (2) identification of relevant studies, (3) selection of studies, (4) data charting, and (5) collation, summarisation and reporting of findings, were undertaken. This review was not registered with PROSPERO as scoping reviews are currently not accepted for registration [28].

2.1. Research Questions. This review was conducted based on the primary research question "How safe is the oral consumption of C. papaya leaf for humans?" This primary question was further expanded to secondary research questions including the following:

(i) What is the documented safe dose range of C. papaya leaf consumption in humans?

(ii) What is the safety profile of C. papaya leaf in animal toxicity studies and how does it potentially translate into negative effects in humans?

(iii) What are the potential herb-drug interactions of C. papaya leaf?

The following Population, Intervention, Comparison, and Outcomes (PICO) framework was applied to address the study's research questions (Table 1 ). Three main population categories were targeted to answer the three secondary research questions.

2.2. Search Strategy. A systematic search was conducted by two independent investigators for published and grey literature with predetermined keywords. In general, a combination of keywords consisting of "papaya," "leaf," "leaves," "side effect," "health effect," "adverse effect," "toxic," "safety," "herb interaction," and "drug interaction" was used, catered, and adapted to each search engine. An example of the keywords search used for MEDLINE is presented in the supplementary material (S1 Appendix). For published papers and ongoing trials, electronic databases MEDLINE, Cochrane Library Central, LILACS (Latin American and Caribbean Health Sciences Literature), and Web of Science were searched for the period since inception until October 2020. Additional grey literature related to safety reports were searched for from the websites of FDA Medwatch, U.S.A National Toxicology Program, European Food Safety Authorities, ProQuest Dissertations \& Theses Global, and the Malaysian Adverse Drug Reactions Advisory Committee (MADRAC) bulletin. Details on Adverse Drug Reaction (ADR) reports related to C. papaya leaf consumption in Malaysia from the MADRAC database were further obtained via an official application [30] to the Pharmacovigilance Section, Centre for Compliance and Quality Control, 
TAble 1: Population, Intervention, Comparison, and Outcomes (PICO) framework.

\begin{tabular}{|c|c|}
\hline Elements & Details \\
\hline \multirow{3}{*}{ Population } & 1. Human patients of all ages and diseases, healthy and unhealthy \\
\hline & 2. Animal models in toxicity studies \\
\hline & 3. Animal models, cell models, or assays in herb-drug interaction studies \\
\hline Intervention & C. papaya leaf as a single herb, in any form of any formulation. Only studies utilizing the leaf part of the plant were included \\
\hline Comparator & Placebo, no treatment, or control treatment \\
\hline \multirow{7}{*}{ Outcome } & Primary outcome: \\
\hline & 1. Safe dosage range and formulations documented \\
\hline & $\begin{array}{l}\text { 2. Intrinsic toxicity data including adverse events and serious adverse events reported in clinical trials or studies which may } \\
\text { or may not be related to treatment }\end{array}$ \\
\hline & 3. Toxicity findings from animal toxicity studies \\
\hline & 4. Reports on herb-drug interaction \\
\hline & Secondary outcome: \\
\hline & $\begin{array}{l}\text { Reporting quality of randomised controlled and quasiexperimental trials specific to quality of herbal medicine interventions } \\
\text { (Consolidated Standards of Reporting Trials (CONSORT) extension for herbal trials, item No. } 4 \text { [29]), an indirect indicator } \\
\text { of extrinsic toxicity of the test item }\end{array}$ \\
\hline
\end{tabular}

National Pharmaceutical Regulatory Agency Malaysia. Additional relevant studies (if any) were also identified from the reference list of related review papers found during the initial search. All searches were performed and matched by two independent investigators. Search results were managed using bibliographic software (EndNote X8.1), and duplicates were removed. For ongoing clinical trials, attempts were made to contact the investigators for relevant information.

2.3. Article Inclusion. Title and abstract screening, as well as full-text paper inclusion, was performed by two independent investigators. A third investigator was involved in cases of disagreements. Studies were selected based on the inclusion and exclusion criteria with reference to the research questions identified and PICO elements (Table 1). The inclusion and exclusion criteria are presented according to the three main questions of this study (Table 2). Similar but specific inclusion and exclusion criteria were applied for each question to optimise data inclusion with the aim of building a well-rounded safety profile for C. papaya leaf consumption. This paper only reviewed $C$. papaya leaf as a whole, adhering to the study objective, and did not take into account compound-based interventions. C. papaya leaf is often consumed as a whole leaf extract for therapeutic use in cases of thrombocytopaenia. The effect of medicinal plants is often due to the collective contribution of several phytochemicals present in the plant; thus, studies on single compounds may not sufficiently represent the real-world usage of $C$. papaya leaf as a whole plant part for therapeutic purposes. Articles investigating C. papaya leaf in combination (as mixtures) with other interventions were also excluded to aid in the analysis of any causal relationship between reported effects and C. papaya leaf as the main contributor. Only English language articles were included.

2.4. Data Charting. Data extraction was carried out and then agreed on by two independent reviewers while disparities were reviewed by a third. Four different data extraction tables (supplementary material: S2 Appendix) were specifically designed for (1) clinical, (2) animal toxicity, (3) pharmacodynamic herb-drug interaction, and (4) pharmacokinetic herb-drug interaction articles to comprehensively capture the required data for different types of study and outcome. All investigators were briefed and trained on using the data extraction tables beforehand to ensure accurate and consistent data extraction.

In general, the categories of main data extracted include the following:

(i) Article identifier: designated number; title; and author

(ii) Article characteristics: year; country; type of study (randomised controlled trials, case series, in vivo, in vitro, etc.); and objectives

(iii) Study population: sample size; drop outs; and details of study population (age, gender, comorbidities, diagnosis, animal model, cells, and assay)

(iv) Intervention: plant part used; form; formulation; quality details, e.g., quantitative analysis, chemical fingerprinting, standardisation, voucher specimen, and source; dose; duration; and cointervention

(v) Comparator: intervention description; formulation; dose; duration; and cointervention

(vi) Outcomes: adverse events or reactions; herb-drug interaction; mechanism of herb-drug interaction; and method of assessment

(vii) Others: limitations; funding details; other reference identified (for tracing of additional papers); and remarks (reasons for exclusion must be stated)

For unpublished ADR reports, the following information was requested from the official providers to enable critical appraisal and descriptive analysis of causality:

(i) Name and details of the ingested C. papaya leaf formulation/product (plant name, plant part, formulation details, dose, frequency, and duration)

(ii) Purpose of C. papaya leaf consumption

(iii) Details of concomitant intervention

(iv) Description of an adverse event 
TABLE 2: Inclusion and exclusion criteria.

\begin{tabular}{|c|c|}
\hline \multicolumn{2}{|c|}{ 2A: clinical studies } \\
\hline $\begin{array}{l}\text { Exclusion } \\
\text { criteria }\end{array}$ & $\begin{array}{l}\text { a) Clinical articles and reports on primary human data } \\
\text { b) Articles that investigated C. papaya leaf as an intervention in all types of formulations including as raw plant, extracts, } \\
\text { juice, tablet, capsule, powder, and syrup, as a single herb } \\
\text { c) Articles that included patients of all ages and health status as study population } \\
\text { a) Review papers or reports on secondary data } \\
\text { b) Articles that investigated isolated compounds as intervention, including C. papaya-leaf-derived compounds } \\
\text { c) Articles that investigated mixture formulations which contain C. papaya leaf as one of their components, along with } \\
\text { other active ingredients } \\
\text { d) Articles that investigated plant parts of } C \text {. papaya apart from leaves }\end{array}$ \\
\hline \multicolumn{2}{|c|}{ 2B: animal toxicity studies } \\
\hline \multirow[b]{2}{*}{ Inclusion criteria } & a) Primary articles of in vivo animal toxicity studies \\
\hline & $\begin{array}{l}\text { b) Articles that investigated C. papaya leaf as an intervention in all types of formulations including as raw plant, extracts, } \\
\text { juice, tablet, capsule, powder, and syrup, as a single herb }\end{array}$ \\
\hline \multirow{5}{*}{$\begin{array}{l}\text { Exclusion } \\
\text { Criteria }\end{array}$} & ondary data \\
\hline & $\begin{array}{l}\text { b) Articles that investigated isolated compounds as interventions, including C. papaya-leaf-derived compounds } \\
\text { c) Articles that investigated mixture formulations which contain C. papaya leaf as one of their components, along with } \\
\text { other active ingredients }\end{array}$ \\
\hline & d) Articles that investigated plant parts of C. papaya apart from leaves \\
\hline & e) Non-in-vivo papers such as in vitro and in silico stu \\
\hline & f) Efficacy papers \\
\hline \multicolumn{2}{|c|}{ 2C: herb-drug interaction studies } \\
\hline \multirow{3}{*}{$\begin{array}{l}\text { Inclusion } \\
\text { Criteria }\end{array}$} & \\
\hline & $\begin{array}{l}\text { b) All study types including clinical (inclusive of all ages and health status) and preclinical (in vivo, in vitro, in silico, and } \\
\text { assay-based) papers }\end{array}$ \\
\hline & $\begin{array}{l}\text { c) Articles that investigated C. papaya leaf as an intervention in all types of formulations including as raw plant, extracts, } \\
\text { juice, tablet, capsule, powder, and syrup, as a single herb }\end{array}$ \\
\hline \multirow{4}{*}{$\begin{array}{l}\text { Exclusion } \\
\text { criteria }\end{array}$} & a) Review papers or reports on seconc \\
\hline & b) Articles that investigated isolated compounds as interventions, including C. papaya-leaf-derived compounds \\
\hline & $\begin{array}{l}\text { c) Articles that investigated mixture formulations which contain C. papaya leaf as one of their components, along with } \\
\text { other active ingredients as the main intervention (this does not refer to the herb/drug in which potential for } \\
\text { interaction was investigated) }\end{array}$ \\
\hline & d) Articles that investigated plant parts of C. papaya apart from leaves \\
\hline
\end{tabular}

(v) Causality score/assessment

(vi) Patient demographics (age, gender, comorbidities, and diagnosis)

2.5. Data Analysis. Due to the versatility in types of studies and results acquired, descriptive numerical analysis was carried out for the country and type of study. A list of ongoing studies and their latest status were tabulated. The toxicity profile of C. papaya leaf was built on collating and descriptively summarising results on safe doses used in clinical settings, adverse reactions reported in clinical articles, and animal toxicity data, as well as evidence of both pharmacokinetic and pharmacodynamic herb-drug interactions.

Specifically for randomised controlled and quasiexperimental trials, the reporting quality of the herbal intervention investigation was assessed using the Consolidated Standards of Reporting Trials (CONSORT) extension for herbal trials, item No. 4 [29]. This was also an indirect representation of data transparency and awareness on declaring potential extrinsic toxicities of the investigated test items by the original authors. Risk of bias assessment was conducted by two independent investigators, with disparities addressed by a third, using the Cochrane Review
Manager (RevMan, version 5.4) software, on all randomised controlled and quasiexperimental trials included. This scoping review was conducted and reported according to the Preferred Reporting Items for Systematic Reviews and MetaAnalyses Extension for Scoping Reviews (PRISMA-SCRs) checklist (S3 Appendix) [31].

\section{Results}

3.1. Study Inclusion. From a total of 322 records identified from the initial search, final 41 articles were included in this scoping review for descriptive analysis, from which 13 randomised controlled and quasiexperimental trials were analysed for risk of bias and test item (herbal intervention) reporting quality (Figure 1). Five registered ongoing trials were also identified. The details of these trials can be found in supplementary material S1 Table. Three related ADR reports from the MADRAC database were successfully retrieved (official information provided through e-mail by the Head of Pharmacovigilance Section, Centre for Compliance and Quality Control, National Pharmaceutical Regulatory Agency, Malaysia). Two out of three ADR reports were included in this review while one was excluded as it involved consumption of an herbal mixture containing C. papaya and other unidentified herbs. 


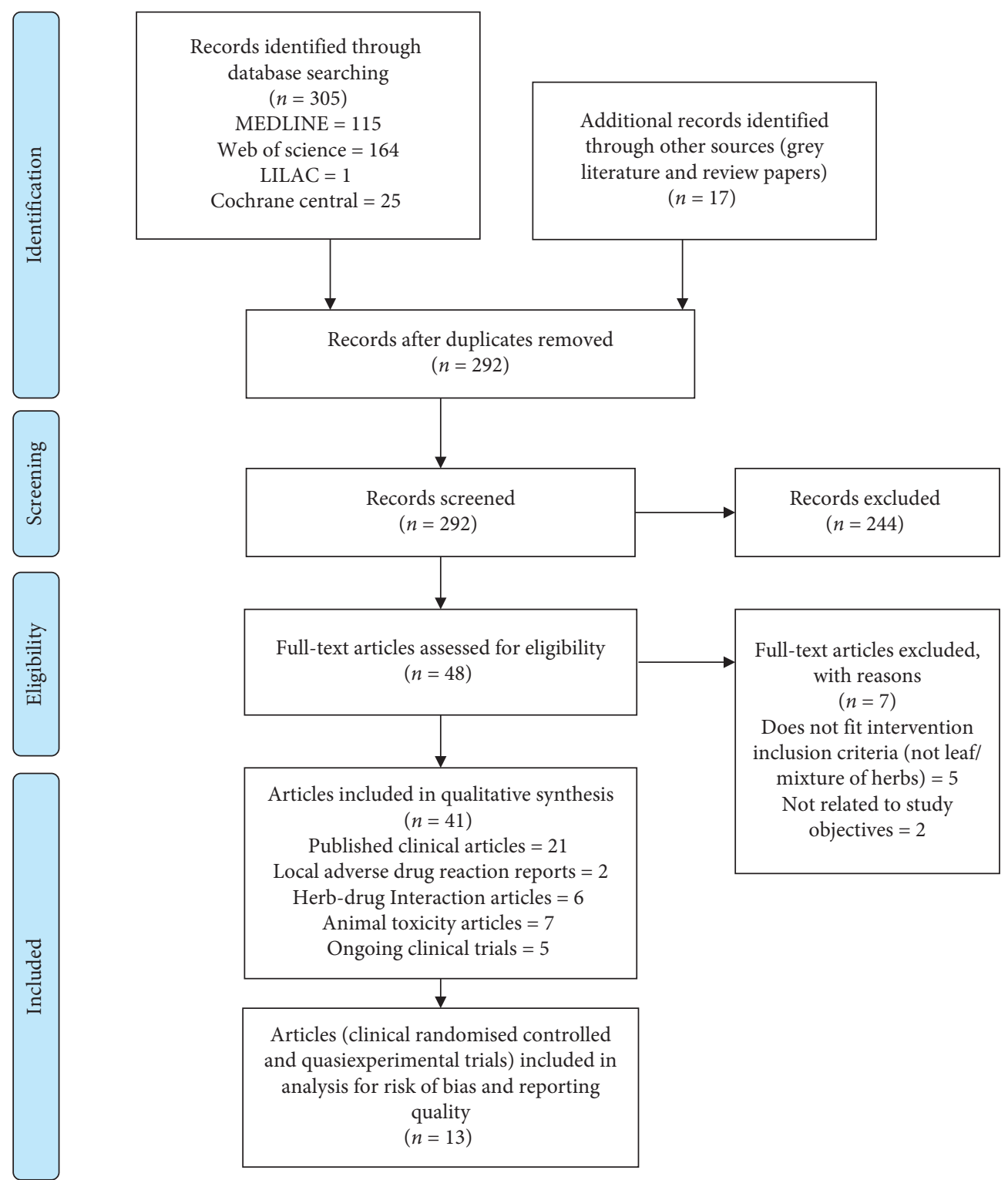

Figure 1: Preferred Reporting Items for Systematic Reviews and Meta-Analyses (PRISMA) flow diagram of included studies.

3.2. Demographics of Included Articles. Table 3 presents the characteristics of all included articles. Among the 23 clinical articles (21 published and 2 unpublished) included, most were randomised controlled trials on dengue patients, with India being the leading country $(52.17 \%)$. All five of the ongoing trials identified also investigated the effects of C. papaya leaf in dengue patients (S1 Table). Both general and specific toxicity studies on rodents and nonrodents were published, mostly reported by Malaysian authors. Few herbdrug interactions were studied at the preclinical level while there were no clinical reports on these interactions (Table 3 ).

3.3. Clinical Evidence on Safety Profile. Details of clinical evidence on the safety profile of $C$. papaya leaf consumption are presented in Table 4 . Among the published papers, $28.6 \%$ of the papers, including $25 \%$ of published randomised control trials, did not explicitly report safety-related findings $[6,36,42]$.
3.4. Adverse Reactions. Based on published clinical evidence, overall, no major adverse reactions related to C. papaya leaf consumption were reported across a wide range of formulations, doses, and durations [5, 6, 32-50]. The most commonly reported side effects were gastrointestinal disturbances, comparable to control groups [5, 37, 39, 41, 50]. Cases of rash observed solely in the C. papaya-leaf-administered group of patients were also reported in two papers, highlighting a risk for allergic reactions [32, 41] (Table 4).

Two cases of unpublished ADR reports retrieved from the MADRAC database reported hepatic enzyme derangements, with a MADRAC causality score [51] of "possible." At the time of reporting, one of the patients was recovering (Alanine Transaminase (ALT) and Aspartate Transaminase (AST) normalisation) after cessation of the C. papaya leaf extract capsule while the other had not (Table 5). 
TABLE 3: Demographics of included articles.

\begin{tabular}{|c|c|c|}
\hline Demographic categories & Frequency (n) & Percentage $(\%)$ \\
\hline \multicolumn{3}{|l|}{ Clinical evidence (published and unpublished) $(n=23)$} \\
\hline \multicolumn{3}{|l|}{ Type of article } \\
\hline Randomised controlled trial & 12 & 52.17 \\
\hline Quasiexperimental trial & 1 & 4.35 \\
\hline Retrospective audit & 1 & 4.35 \\
\hline Case report/series & 7 & 30.43 \\
\hline Other unpublished reports & 2 & 8.70 \\
\hline \multicolumn{3}{|l|}{ Indication } \\
\hline Dengue & 15 & 65.22 \\
\hline Chemotherapy-induced thrombocytopaenia & 3 & 13.04 \\
\hline Cancer & 1 & 4.35 \\
\hline Chronic immune thrombocytopaenia purpura & 1 & 4.35 \\
\hline Febrile thrombocytopaenia & 1 & 4.35 \\
\hline General health & 1 & 4.35 \\
\hline Neonatal thrombocytopaenia & 1 & 4.35 \\
\hline \multicolumn{3}{|l|}{ Country } \\
\hline India & 12 & 52.17 \\
\hline Malaysia & 3 & 13.04 \\
\hline Pakistan & 3 & 13.04 \\
\hline U.S.A & 2 & 8.70 \\
\hline Bangladesh & 1 & 4.35 \\
\hline Indonesia & 1 & 4.35 \\
\hline Sri Lanka & 1 & 4.35 \\
\hline \multicolumn{3}{|l|}{ Preclinical in vivo toxicity studies $(n=7)$} \\
\hline \multicolumn{3}{|l|}{ Type of study } \\
\hline General toxicity & 5 & 71.43 \\
\hline Specific toxicity & 1 & 14.29 \\
\hline Combination (general and specific) & 1 & 14.29 \\
\hline \multicolumn{3}{|l|}{ Animal model } \\
\hline Rodent & 5 & 71.43 \\
\hline Nonrodent & 2 & 28.57 \\
\hline \multicolumn{3}{|l|}{ Country } \\
\hline Malaysia & 3 & 42.86 \\
\hline Nigeria & 2 & 28.57 \\
\hline Ghana & 1 & 14.29 \\
\hline Brazil & 1 & 14.29 \\
\hline \multicolumn{3}{|l|}{ Herb-drug interaction studies $(n=6)$} \\
\hline \multicolumn{3}{|l|}{ Type of study } \\
\hline Pharmacokinetic & 2 & 33.33 \\
\hline Pharmacodynamic & 4 & 66.67 \\
\hline \multicolumn{3}{|l|}{ Study model } \\
\hline In vivo & 3 & 50.00 \\
\hline In vitro & 2 & 33.33 \\
\hline Combination (in vitro and in vivo) & 1 & 16.67 \\
\hline \multicolumn{3}{|l|}{ Country } \\
\hline Nigeria & 3 & 50.00 \\
\hline Italy & 2 & 33.33 \\
\hline Japan & 1 & 16.67 \\
\hline
\end{tabular}

3.5. Herbal Intervention/Test Item Reporting Quality, Selection, Dosage Range, and Duration. Analysis of reporting quality on the herbal intervention/test item based on CONSORT checklist item No. 4 is presented in S4 Appendix. Nearly all of the published randomised controlled and quasiexperimental trials did not report on most of the recommended important reporting items pertaining to the test item quality. Only one paper (7\%) [6] reported that heavy-metal levels were within allowable limits. Factors that may contribute towards extrinsic toxicities such as purity testing for heavy-metal or other contaminant testing were not reported in the other 12 papers. Although the brand name Caripill was mentioned in a few papers, the name of the manufacturer (Microlabs), details on extract (aqueous extract), and the standardised content of $40 \%$ glycoside were not specifically reported in text. However, based on the collective understanding of the investigators and information available online [52], all trials involving Caripill tablet and syrup reported here were assumed to be manufactured by Microlabs for further descriptive and risk of bias analysis. 


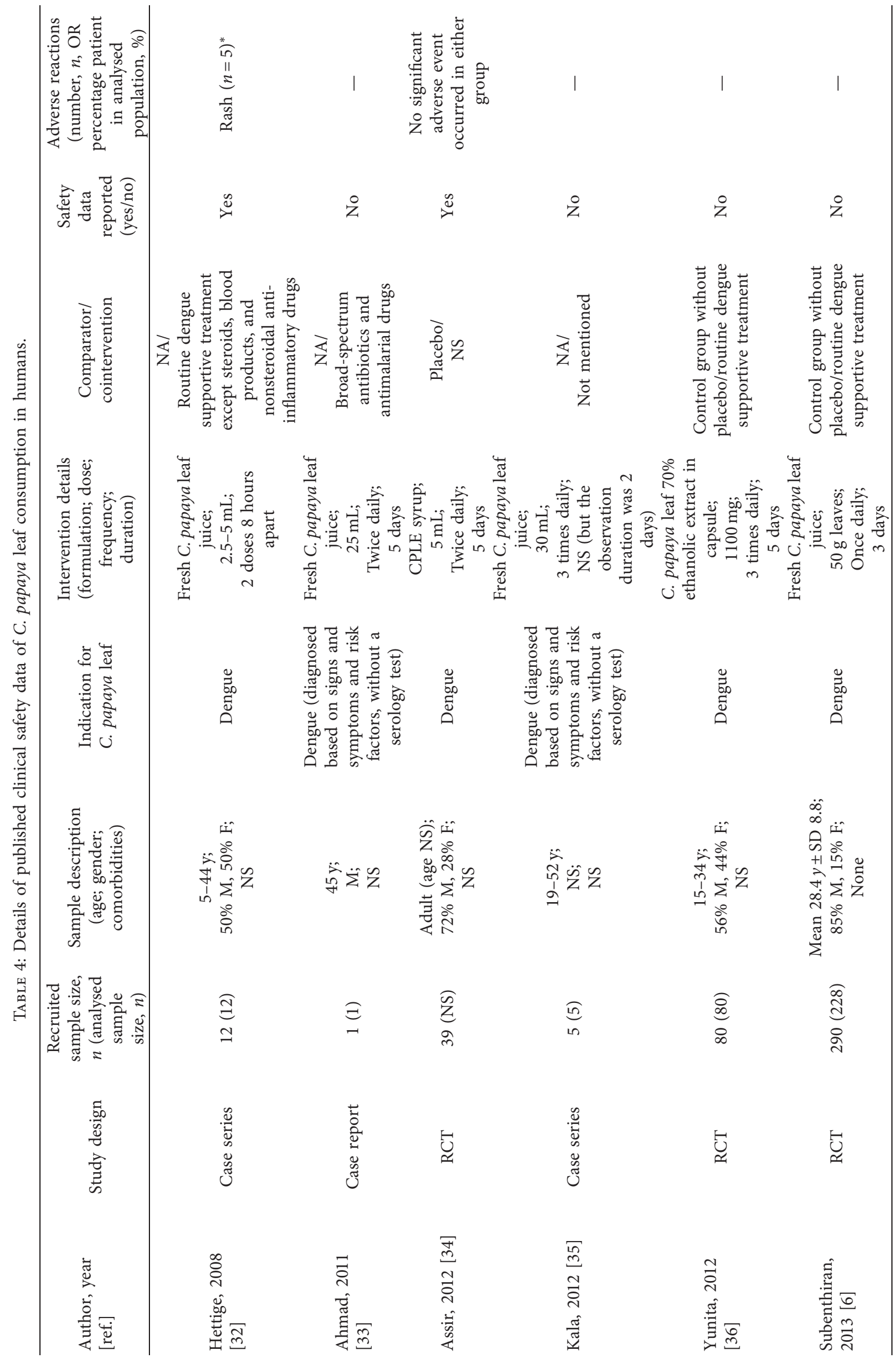




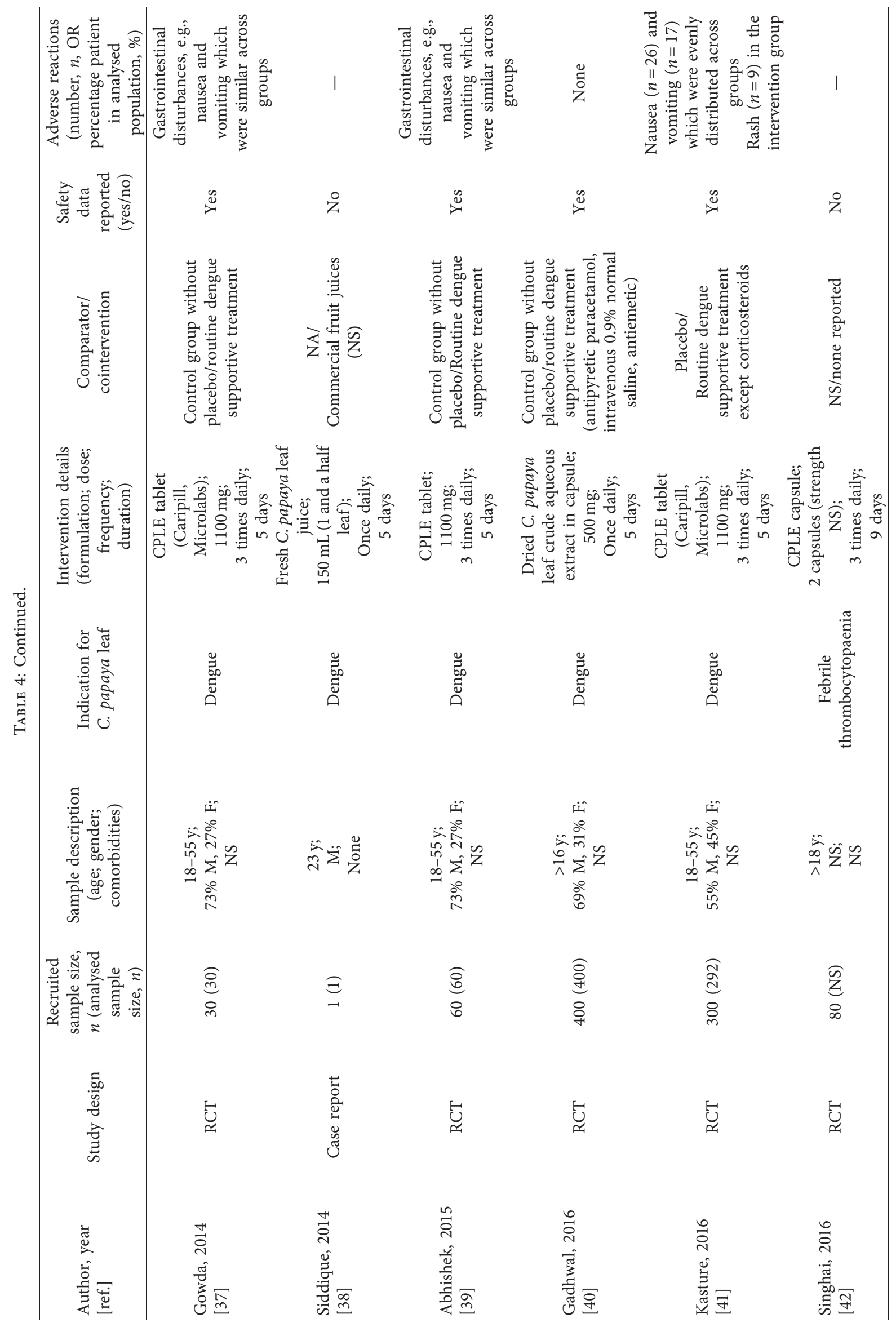




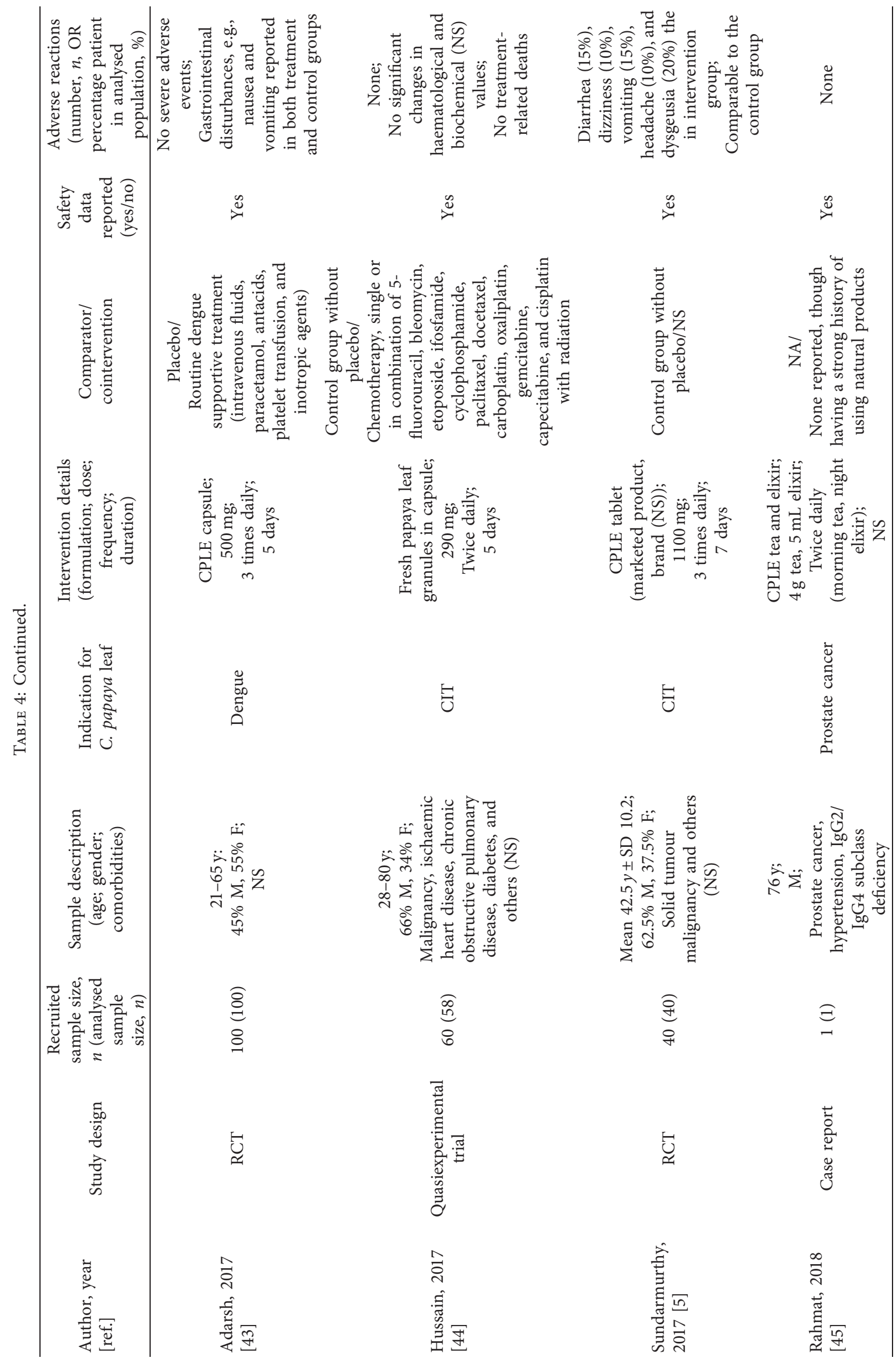




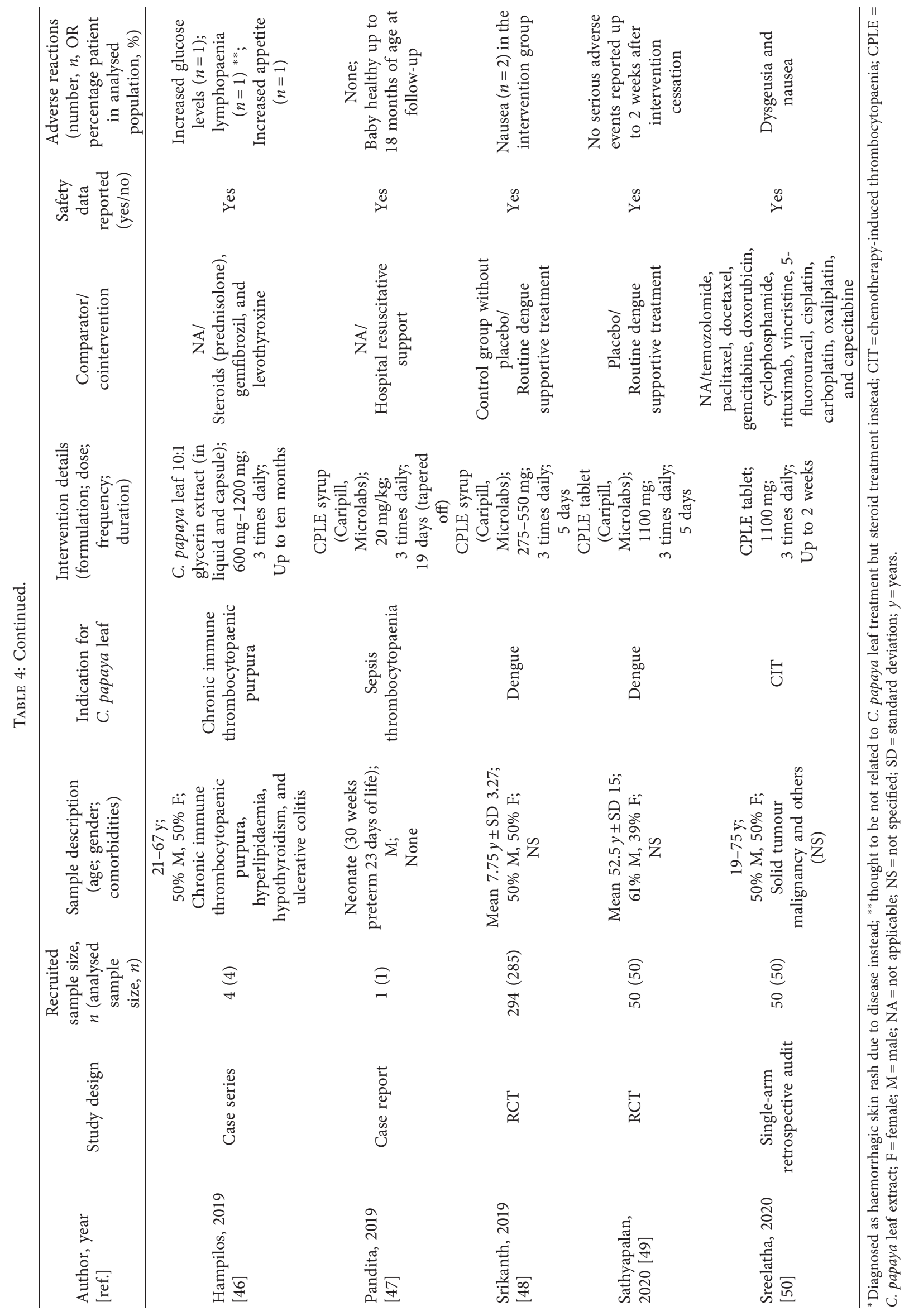


TABLE 5: Details of unpublished adverse drug reaction (ADR) reports of C. papaya leaf consumption in humans.

\begin{tabular}{|c|c|c|c|c|c|c|c|c|}
\hline $\begin{array}{l}\text { Report } \\
\text { no. }\end{array}$ & Gender & $\begin{array}{c}\text { Age } \\
\text { (years) }\end{array}$ & $\begin{array}{c}\text { ADR } \\
\text { description }\end{array}$ & $\begin{array}{l}\text { Indication } \\
\text { for C. papaya } \\
\text { leaf }\end{array}$ & $\begin{array}{l}\text { Intervention details } \\
\text { (formulation; dose; } \\
\text { frequency; duration) }\end{array}$ & $\begin{array}{c}\text { Additional laboratory } \\
\text { evaluation (adulteration } \\
\text { and heavy-metal analysis) }\end{array}$ & $\begin{array}{l}\text { Potential } \\
\text { confounding } \\
\text { factors (e.g., } \\
\text { concomitant } \\
\text { medications/ } \\
\text { comorbidities) }\end{array}$ & $\begin{array}{l}\text { MADRAC } \\
\text { causality } \\
\text { assessment }\end{array}$ \\
\hline 1 & Male & 17 & $\begin{array}{l}\text { Deranged liver } \\
\text { enzymes after } 6 \\
\text { days of } \\
\text { consumption } \\
\text { reported in a } \\
\text { patient } \\
\text { diagnosed with } \\
\text { dengue fever }\end{array}$ & Dengue & $\begin{array}{l}\text { C. papaya leaf } \\
\text { extract; } \\
600 \mathrm{mg} ; \\
\text { Once daily; } \\
6 \text { days }\end{array}$ & $\begin{array}{l}\text { Negative detection for } \\
\text { paracetamol and } \\
\text { nonsteroidal anti- } \\
\text { inflammatory drugs; } \\
\text { heavy-metal levels within } \\
\text { allowable limits }\end{array}$ & Not specified & Possible \\
\hline 2 & Female & 37 & $\begin{array}{l}\text { Transaminitis } \\
\text { with } \\
\text { accompanying } \\
\text { symptoms of } \\
\text { fever, } \\
\text { vomiting, } \\
\text { diarrhea, loss } \\
\text { of appetite, and } \\
\text { lethargy }\end{array}$ & General health & $\begin{array}{l}\text { C. papaya leaf } \\
\text { extract; } \\
600 \mathrm{mg} ; \\
\text { Once daily; } \\
3 \text { days }\end{array}$ & $\begin{array}{c}\text { Negative detection for } \\
\text { steroids; heavy-metal } \\
\text { levels within allowable } \\
\text { limits }\end{array}$ & Not specified & Possible \\
\hline
\end{tabular}

Source: Pharmacovigilance Section, Centre for Compliance and Quality Control, National Pharmaceutical Regulatory Agency, Malaysia; ADR = adverse drug reaction; MADRAC = Malaysian Adverse Drug Reactions Advisory Committee.

Overall, $61 \%$ of the included articles mentioned the type of extract used as an intervention. The most commonly investigated formulation in the clinical articles included was juice $(26 \%)$ followed by a commercialised standardised aqueous extract of $C$. papaya leaf containing $40 \%$ glycosides (Caripill, Microlabs) (21.7\%). There were no reports on quantitative or standardised biomarkers of the juice. Nine papers reported the use of $C$. papaya leaf extract without specifying the type of extract. In general, C. papaya leaf juice was reportedly given at doses ranging from $2.5 \mathrm{~mL}$ in children to up to $150 \mathrm{~mL}$ a day in adults (Table 4). The youngest patient to be safely administered with $20 \mathrm{mg} / \mathrm{kg}$ C. papaya leaf standardised aqueous extract (Caripill, Microlabs) was a preterm neonate at 23 days of life [47]. In terms of duration, C. papaya leaf extract and juice were administered only for a short duration of three to five days in randomised controlled and quasiexperimental trials, mostly in dengue patients. A longer duration of consumption of a 10:1 glycerin extract, for up to ten months, was reported in case reports of patients with chronic immune thrombocytopaenic purpura (Table 4).

For the two unpublished ADR reports of liver enzyme derangements, the dose of C. papaya leaf extract capsule administered was $600 \mathrm{mg}$ once daily over a short duration of three to six days, with incomplete details on the type of extract and concomitant medications, as well as underlying comorbidities and preexisting hepatic impairment risk factors of the patients (Table 5).

3.6. Risk of Bias Analysis. Risk of bias analysis (Figure 2) of 13 randomised controlled and quasiexperimental trials showed that proper blinding of participants and personnel was only achieved in $15.4 \%(n=2 / 13)$ of the studies. Performance bias was the most highly rated bias in the included articles $(61.54 \%, n=8 / 13)$. Most of these studies did not include administration of a formulated placebo in the control group. Although reported as randomised controlled trials, only four papers explicitly reported the details of randomisation methods (computer generated table, online randomisation software, odd-even method, and block-of10) to achieve low selection bias while randomisation methods were not specified for the remaining 9 studies. Reporting bias was found to be equally low and high in $38.5 \%(n=5 / 13)$ of the studies. Five studies were categorised as containing high reporting bias due to missing reports on safety data including biochemical investigations of renal and hepatic function. Three papers were categorised as having high risk of other biases were either industry sponsored or authored by personnel from the company who manufactured the herbal intervention/test item. A summary on riskof-bias analysis for individual papers is presented in Figure 3.

3.7. Animal Toxicity Studies. Details and findings of animal toxicity studies of the oral $C$. papaya leaf are presented in Table 6. In general, C. papaya leaf juice and aqueous extract are nontoxic at high doses up to $2000 \mathrm{mg} / \mathrm{kg}$ in rats administered as a single dose $[55,57]$. There was also no mortality reported in any animal toxicity studies regardless of dose (up to $2000 \mathrm{mg} / \mathrm{kg}$ ), duration (up to 24 weeks), and formulation [53-59]. However, there are some concerns on the hepatotoxic effects of long-term administration. In rats administered with freeze-dried C. papaya leaf juice for 21 days, raised ALT and Alkaline Phosphatase (ALP) levels 


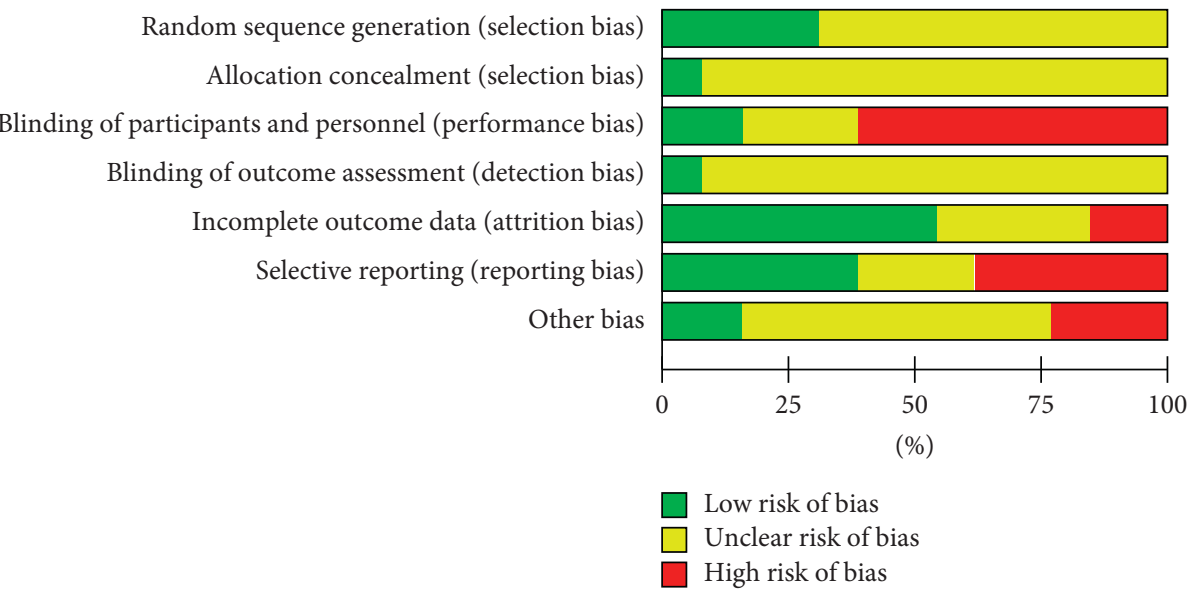

FIGURE 2: Risk of bias analysis of included randomised controlled and quasiexperimental trials $(n=13)$.

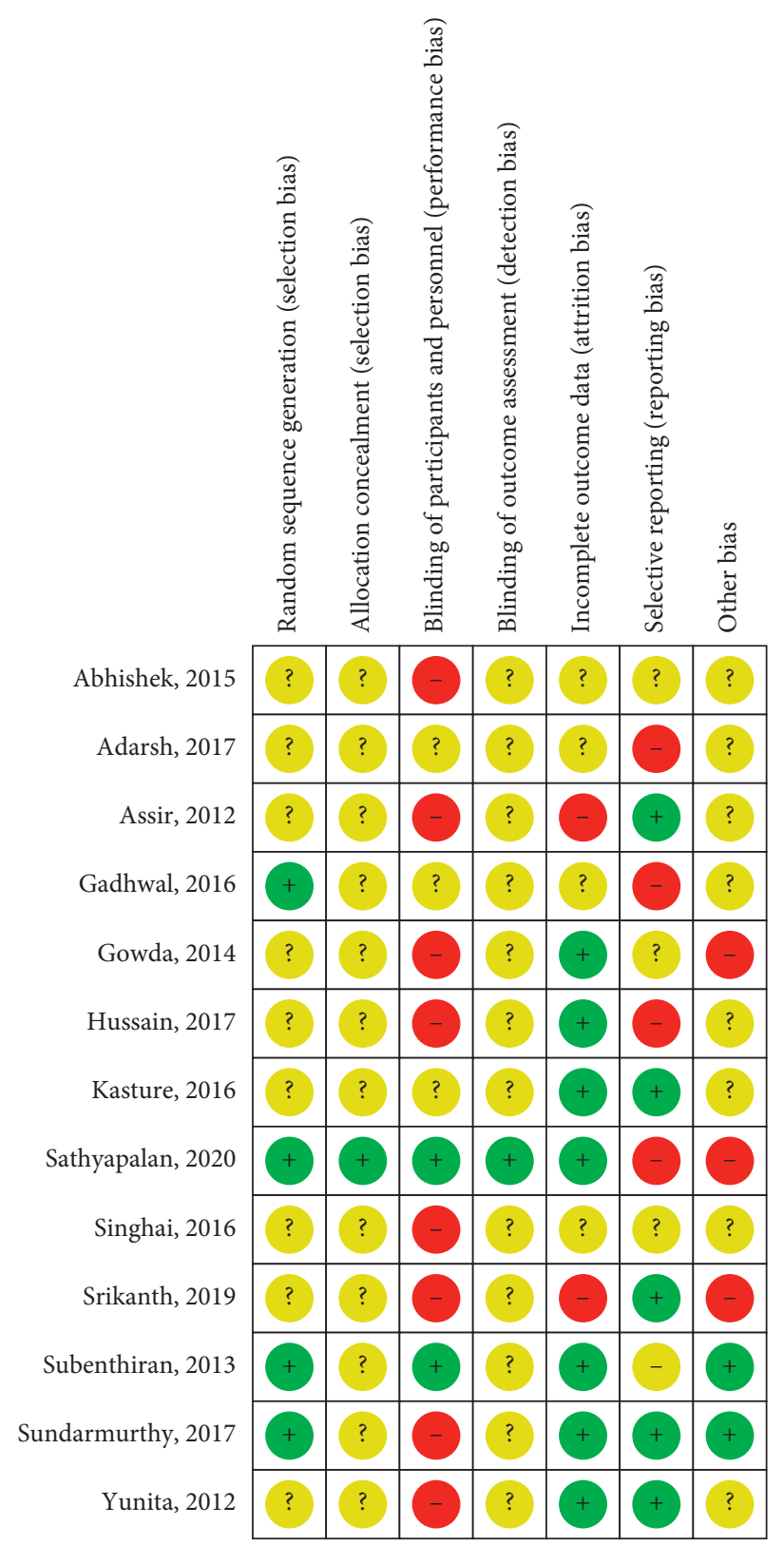

FIGURE 3: Risk of bias analysis summary for individual randomised controlled and quasiexperimental trials $(n=13)$. Green and “+” low risk, yellow and "?" = unclear risk, and red and "-" = high risk. 
TABLE 6: In vivo animal toxicity studies of orally administered C. papaya leaf.

\begin{tabular}{|c|c|c|c|c|c|}
\hline $\begin{array}{l}\text { Author, year } \\
\text { [ref.] }\end{array}$ & $\begin{array}{l}\text { Animal model } \\
\text { (species; } \\
\text { gender) }\end{array}$ & $\begin{array}{l}\text { Intervention details } \\
\text { (formulation; dose; } \\
\text { frequency; duration; } \\
\text { quantitative analysis of } \\
\text { content) }\end{array}$ & Comparator & $\begin{array}{l}\text { Quantitation of toxic/ } \\
\text { safe dose }\end{array}$ & Description of toxicity findings \\
\hline $\begin{array}{l}\text { Akinloye, } \\
2010[53]\end{array}$ & $\begin{array}{l}\text { Rat (Wistar; } \\
\text { Male) }\end{array}$ & $\begin{array}{c}\text { Air-dried C. papaya leaf } \\
\text { decoction; } \\
500 \mathrm{mg} / \mathrm{kg} ; \\
\text { Daily; } \\
21 \text { days; } \\
\text { NS }\end{array}$ & $\begin{array}{l}0.9 \% \text { sodium } \\
\text { chloride }\end{array}$ & NA & (i) Male reproductive toxicity \\
\hline $\begin{array}{l}\text { Omonkhua, } \\
2011[54]\end{array}$ & $\begin{array}{l}\text { Rabbits (New } \\
\text { Zealand; NS) }\end{array}$ & $\begin{array}{c}\text { C. papaya leaf aqueous } \\
\text { extract; } \\
200 \mathrm{mg} / \mathrm{kg} ; \\
\text { Daily; } \\
24 \text { weeks; } \\
\text { NS }\end{array}$ & Water & NA & $\begin{array}{l}\text { (i) Transient elevation of liver } \\
\text { enzymes (ALP, GGT, and } \\
\text { bilirubin) at initial periods of } \\
\text { treatment ( } 3 \text { to } 5 \text { weeks); } \\
\text { ) Risk of bile duct obstruction }\end{array}$ \\
\hline $\begin{array}{l}\text { Halim, } 2011 \\
\text { [55] }\end{array}$ & $\begin{array}{l}\text { Rat (Sprague } \\
\text { Dawley; } \\
\text { female) }\end{array}$ & $\begin{array}{l}\text { Freeze-dried C. papaya leaf } \\
\text { aqueous extract; } \\
5,50,300 \text {, and } 2000 \mathrm{mg} / \mathrm{kg} ; \\
\text { Once; } \\
\text { Single dose; } \\
\text { NS }\end{array}$ & Water & NS & $\begin{array}{l}\text { (i) No mortality and acute } \\
\text { adverse events at all doses; } \\
\text { (ii) Raised HGB, HCT, RBC, TG, } \\
\text { and total protein levels at } \\
2000 \mathrm{mg} / \mathrm{kg} \text {; } \\
\text { (iii) No relative organ weight and } \\
\text { gross histopathology changes }\end{array}$ \\
\hline $\begin{array}{l}\text { Afzan, } 2012 \\
{[56]}\end{array}$ & $\begin{array}{l}\text { Rat (Sprague } \\
\text { Dawley; male } \\
\text { and female) }\end{array}$ & $\begin{array}{c}\text { Lypohilised fresh C. papaya } \\
\text { leaf juice; } \\
\text { 10, 140, and } 2000 \mathrm{mg} / \mathrm{kg} ; \\
\text { Daily; } \\
28 \text { days; } \\
\text { NS }\end{array}$ & Water & NS & $\begin{array}{l}\text { (i) No mortality and acute } \\
\text { adverse events at all doses; } \\
\text { (ii) No abnormalities in serum } \\
\text { haematology; } \\
\text { (iii) Raised ALT and ALP levels } \\
\text { at } 10 \mathrm{mg} / \mathrm{kg} \text { and } 140 \mathrm{mg} / \mathrm{kg} \text { (male } \\
\text { and female); } \\
\text { (iv) Raised total protein, AST, } \\
\text { and HDL at } 140 \mathrm{mg} / \mathrm{kg} \text { (female); } \\
\text { (v) No relative organ weight and }\end{array}$ \\
\hline $\begin{array}{l}\text { Ismail, } 2014 \\
\text { [57] }\end{array}$ & $\begin{array}{l}\text { Rat (Sprague } \\
\text { Dawley; male } \\
\text { and female) }\end{array}$ & $\begin{array}{l}\text { Freeze-dried fresh C. papaya } \\
\text { leaf juice; } \\
\text { 10, 140, and } 2000 \mathrm{mg} / \mathrm{kg} ; \\
13 \text { weeks; } \\
\text { NS }\end{array}$ & Water & $\begin{array}{c}\text { NOAEL }=2000 \mathrm{mg} / \mathrm{kg} \\
(\text { male and female })\end{array}$ & $\begin{array}{l}\text { histopathology changes } \\
\text { (i) No mortality and acute } \\
\text { adverse events, no changes in } \\
\text { body weight and food and water } \\
\text { intake at all doses; } \\
\text { (ii) No abnormalities in serum } \\
\text { haematology; } \\
\text { (iii) Raised LDH at } 2000 \mathrm{mg} / \mathrm{kg} \\
\text { (male); } \\
\text { (iv) Raised albumin at } 140 \mathrm{mg} / \mathrm{kg} \\
\text { (male); } \\
\text { (v) Raised protein and albumin } \\
\text { at } 140 \text { and } 2000 \mathrm{mg} / \mathrm{kg} \text { (female); } \\
\text { (vi) Reduced creatinine at } \\
2000 \mathrm{mg} / \mathrm{kg} \text { (male and female); } \\
\text { (vii) No relative organ weight } \\
\text { and histopathology changes }\end{array}$ \\
\hline
\end{tabular}


TABLE 6: Continued.

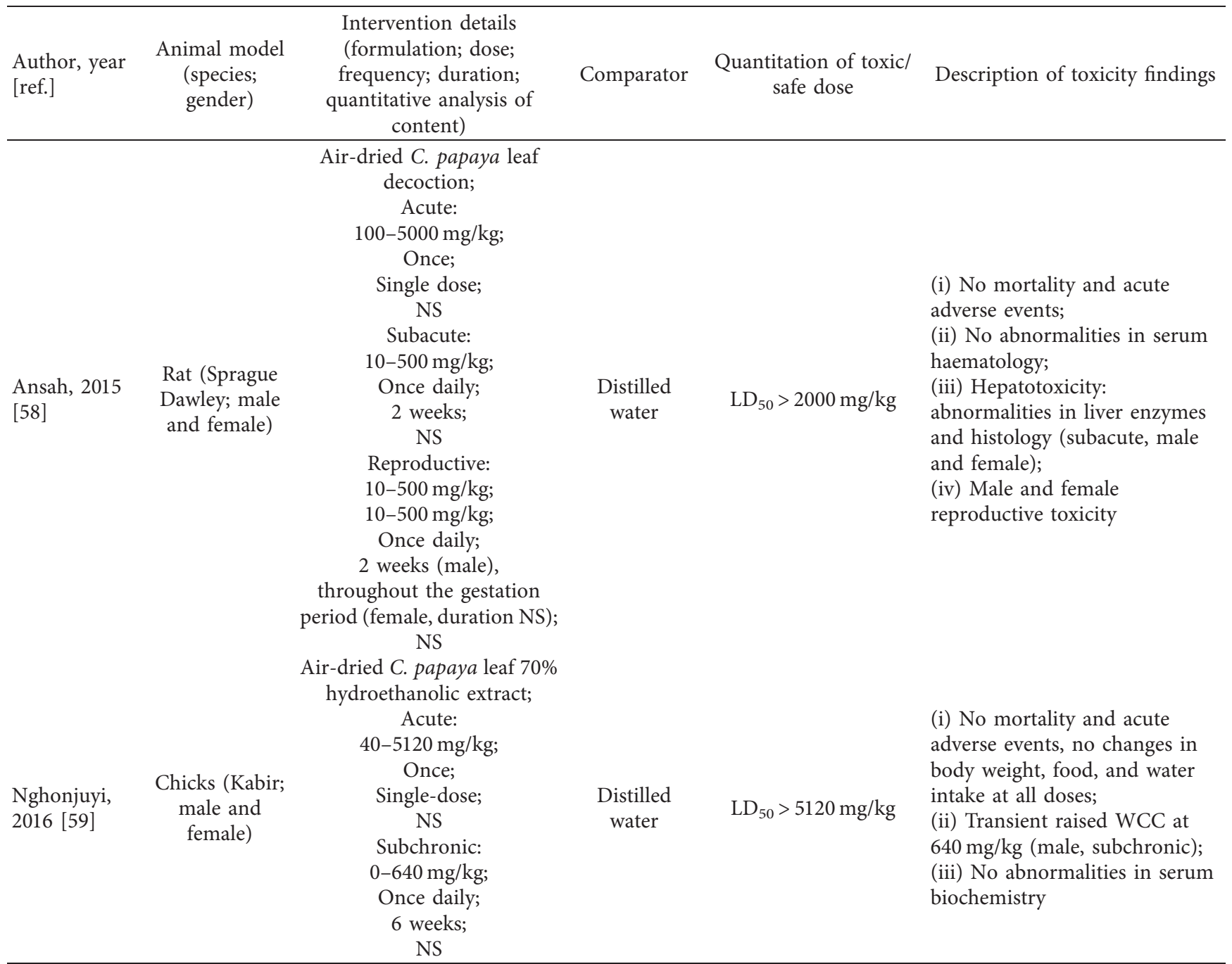

$\mathrm{ALP}=$ alkaline phosphatase; ALT=alanine transaminase; AST=aspartate aminotransferase; GGT=gamma-glutamyl transferase; HGB =haemoglobin; $\mathrm{HCT}=$ haematocrit; $\mathrm{HDL}=$ high-density lipoprotein $\mathrm{LD}_{50}=$ median lethal dose; $\mathrm{LDH}=$ lactate dehydrogenase; $\mathrm{NA}=$ not applicable; $\mathrm{NOAEL}=$ no-observedadverse-effect level; $\mathrm{NS}=$ not specified; $\mathrm{RBC}=$ red blood cell counts; $\mathrm{TG}=$ triglyceride; $\mathrm{WCC}=$ white blood cell counts.

were observed at $10 \mathrm{mg} / \mathrm{kg}$ and $140 \mathrm{mg} / \mathrm{kg}$ for males and females, respectively. Elevated total protein and AST were also observed in female rats administered with $140 \mathrm{mg} / \mathrm{kg}$ freeze-dried C. papaya leaf juice in the same study. However, there were no histopathological changes in the liver postmortem [56]. C. papaya leaf aqueous extract $(200 \mathrm{mg} / \mathrm{kg}$ daily) given for 24 weeks in rabbits also resulted in the elevation of liver enzymes (ALP, Gamma-Glutamyl Transferase (GGT), and bilirubin) at initial periods of treatment which later subsided after week five [54]. Similar liver enzyme changes were also observed in rats administered with air-dried C. papaya leaf decoction at doses $10 \mathrm{mg} / \mathrm{kg}$ and above. In the same study, significant reproductive toxicity in male $(\geq 10 \mathrm{mg} / \mathrm{kg})$ and female $(\geq 60 \mathrm{mg} / \mathrm{kg})$ rats was reported [58]. No specific phytochemical compound was objectively correlated as the main contributor of any toxicity in these studies as there is insufficient reporting on quantitative data of the chemical markers and phytochemical constituents in each individual study.
3.8. Herb-Drug Interactions. Six preclinical studies reported several differential herb-drug interactions between oral administration of C. papaya leaf with oral hypoglycaemic agents (metformin and glimepiride), antimalarial (artemisinin), antibiotic (ciprofloxacin), and cardiovascular drug (digoxin). No specific compounds or biomarkers of C. papaya leaf were objectively identified as the main contributor of interaction (Table 7).

\section{Discussion}

Thrombocytopaenia in dengue fever remains the most investigated indication of C. papaya leaf in clinical studies $[6,32-41,43,48-50]$. This is also reflected in the list of registered ongoing clinical trials ( $\mathrm{S} 1 \mathrm{Table})$. A majority of both published and ongoing studies are conducted by countries (e.g., India, Malaysia, and Pakistan) with interest in utilising C. papaya leaf for diseases of high local prevalence such as dengue $[66,67]$. Arachidonate 12-lipoxygenase 
TABle 7: Herb-drug interaction studies of C. papaya leaf.

\begin{tabular}{|c|c|c|c|c|c|}
\hline $\begin{array}{l}\text { Author, } \\
\text { year [ref.] }\end{array}$ & $\begin{array}{l}\text { Study type } \\
\text { (animal } \\
\text { model, if } \\
\text { any) }\end{array}$ & $\begin{array}{c}\text { C. papaya formulation } \\
\text { details (formulation; } \\
\text { dose; frequency; duration; } \\
\text { biomarker) }\end{array}$ & $\begin{array}{c}\text { Drug } \\
\text { candidate(s) of } \\
\text { interaction }\end{array}$ & Outcome of interaction & Proposed type of interaction \\
\hline $\begin{array}{l}\text { Fakeye, } \\
2007[60]\end{array}$ & In vivo (rat) & $\begin{array}{c}\text { Dried C. papaya leaf } 96 \% \\
\text { ethanolic extract; } \\
5 \mathrm{mg} / \mathrm{kg} \text { and } 10 \mathrm{mg} / \mathrm{kg} ; \\
3 \text { and } 7 \text { days; } \\
\text { NS }\end{array}$ & $\begin{array}{l}\text { Metformin, } \\
\text { glimepiride }\end{array}$ & $\begin{array}{c}\text { Enhanced } \\
\text { hypoglycaemic effect }\end{array}$ & Pharmacokinetic + pharmacodynamic \\
\hline $\begin{array}{l}\text { Sanella, } \\
2009[61]\end{array}$ & In vitro & $\begin{array}{c}\text { Dried C. papaya leaf } \\
\text { decoction; } \\
100 \text { and } 150 \mu \mathrm{g} / \mathrm{mL} ; \\
\text { NA; } \\
\text { Total flavanoids } \\
\text { (expressed as rutin) } \\
\text { Fresh C. papaya leaf crude }\end{array}$ & Artemisinin & $\begin{array}{l}\text { Synergisim in inhibiting } \\
\text { growth of Plasmodium } \\
\text { falciparum }\end{array}$ & Pharmacodynamic \\
\hline $\begin{array}{l}\text { Onaku, } \\
2011[62]\end{array}$ & $\begin{array}{l}\text { In vivo } \\
\text { (mouse) }\end{array}$ & $\begin{array}{l}\text { aqueous extract; } \\
\text { 50-200 mg/kg; } \\
\text { At 4, 24, } 48 \text { and } 72 \text { hours } \\
\text { after Plasmodium berghei } \\
\text { infection; } \\
\text { NS }\end{array}$ & Artemisinin & $\begin{array}{c}\text { Antagonism in } \\
\text { percentage reduction of } \\
\text { parasitaemia } \\
(P . \text { berghei })\end{array}$ & Pharmacodynamic \\
\hline $\begin{array}{l}\text { Oga, } 2012 \\
{[63]}\end{array}$ & In vitro & $\begin{array}{c}\text { Dried C. papaya leaf } \\
\text { decoction of aqueous } \\
\text { extract; } \\
0.02-20 \mathrm{mg} / \mathrm{mL} ; \\
\text { Single dose; } \\
\text { NA; } \\
\text { NS }\end{array}$ & Digoxin & $\begin{array}{l}\text { Inhibition of } \mathrm{p} \text { - } \\
\text { glycoprotein transport } \\
\text { of digoxin }\end{array}$ & Pharmacokinetic \\
\hline $\begin{array}{l}\text { Ukpo, } \\
2017[64]\end{array}$ & $\begin{array}{l}\text { In vivo } \\
\text { (rabbit) }\end{array}$ & $\begin{array}{c}\text { Freeze-dried crude } \\
\text { C. papaya leaf aqueous } \\
\text { extract; } \\
500 \mathrm{mg} / \mathrm{kg} ; \\
\text { Single dose; } \\
\text { NA; } \\
\text { NS }\end{array}$ & Ciprofloxacin & $\begin{array}{l}\text { Reduced absorption } \\
\text { and serum half-life of } \\
\text { ciprofloxacin }\end{array}$ & Pharmacokinetic \\
\hline $\begin{array}{l}\text { Sanella, } \\
2019[65]\end{array}$ & $\begin{array}{l}\text { In vivo } \\
\text { (mouse) and } \\
\text { in vitro }\end{array}$ & $\begin{array}{c}\text { Dried C. papaya leaf } \\
\text { decoction; } \\
100 \text { and } 150 \mu \mathrm{g} / \mathrm{mL} \text { (in } \\
\text { vitro), } 250 \mathrm{mg} / \mathrm{kg} / \text { day (in } \\
\text { vivo); } \\
14 \text { days (in vivo); } \\
\text { Total flavanoids } \\
\text { (expressed as rutin) }\end{array}$ & Artemisinin & $\begin{array}{c}\text { Subsynergism in } \\
\text { inhibiting } P . \text { falciparum } \\
\text { growth }\end{array}$ & Pharmacodynamic \\
\hline
\end{tabular}

(ALOX12) gene activity enhancement is thought to be one of the important mechanisms of improving platelet counts by C. papaya leaf [6]. Hence, in recent years, there is growing interest in the use of C. papaya leaf for non-dengue-infection-related thrombocytopaenia such as chemotherapyinduced thrombocytopaenia $[5,44]$.

\subsection{Intrinsic Toxicity}

4.1.1. Clinical Evidence. Oral consumption of C. papaya leaf is generally well tolerated across a variety of formulations (mostly as juice and aqueous extract) in adults though highquality and comprehensive safety data has not been well documented. C. papaya leaves were mostly administered for a short duration of up to five days $[6,32-34,36,37$, 39-44, 48,49], though longer durations of administration have been reported to be tolerable [46]. Based on the published literature, mild gastrointestinal disturbances were most commonly reported $[5,6,32-50]$. Rash was reported in two papers in the C. papaya leaf juice and aqueous extracts intervention group solely $[32,41]$. Although there may be some concerns on allergic reactions, no serious adverse events such as cases of anaphylaxis were reported in all included clinical articles.

Two cases of liver enzyme derangements were identified from unpublished local ADR reports, which documented a "possible" causal relationship of $C$. papaya leaf extract with the adverse event. These two reports involved consumption of a locally registered product within the recommended dose 
of the specific product for short duration of time (three to six days). Additional laboratory quality assessments also ruled out heavy-metal contamination and product adulteration. Hepatic side effects of $C$. papaya leaf were not reported in any other published clinical evidence regardless of formulation, age, dose, and duration of exposure. However, in most of the randomised controlled studies, patients with underlying liver impairments and abnormal liver enzymes were already excluded from participation $[5,6,37$, $39-41,48,49]$. It is inherently challenging to make accurate causality assessments in voluntary ADR reporting due to the anecdotal nature of ADR reports. Furthermore, outcomes of causality assessment are heavily influenced by an individual reporter's judgement. For example, factors such as knowledge and familiarity with the ADR reporting form components can vastly affect causality scorings [51]. In both reports, the contribution of confounding factors such as concomitant medications or underlying medical conditions was unclear.

In herbal medicine development, it is well established that several confounding factors such as the agroclimatic factors and types of extraction solvent used can influence the final phytochemical composition of a formulation, which may, in turn, affect efficacy and toxicity [68-70]. Therefore, acceptable safe dose range and duration based on clinical trials are only specific to each formulation as reported in the literature, e.g., $1100 \mathrm{mg}$ three times daily for standardised aqueous extract to $40 \%$ glycoside for up to 5 days [49]. In published trials, there is insufficient reporting and data transparency on the quantitative analysis of the composition of most test items. Reporting bias with missing data of safety-related laboratory investigations such as biochemical test results of renal and liver functions was also observed. Therefore, with currently available evidence, it is challenging to deduce a safe dose of C. papaya leaf specific to its phytochemical composition. Specifically in paediatric cases, only one randomised controlled trial among dengue-infected children was conducted and published [48], while one case series [32] and one case report [47] documented the safe administration of $C$. papaya leaf extract in young children. Future trials with detailed quantitative assessment of phytochemical analysis, specialised investigations in paediatric population, and improved ADR reporting are needed to strengthen safety findings. Such data are valuable in providing input for the development of comprehensive clinical guidelines.

4.1.2. Animal Studies. Extrapolating from animal toxicity studies, elevated liver enzymes have been reported in rats and rabbits administered with repeated doses of $C$. papaya leaf juice and aqueous extracts, as well as decoction [54, 56-58]. One paper reported histopathological fatty changes and fibrosis in the liver, as well as haemorrhage and inflammation in the hepatic portal tract of rats administered with air-dried C. papaya leaf decoction $(140 \mathrm{mg} / \mathrm{kg}$ for two weeks) [58]. Time-course evaluation of the effects of C. papaya leaf aqueous extract $(200 \mathrm{mg} / \mathrm{kg}, 24$ weeks) on rabbit hepatic enzymes revealed transient elevation of ALP,
GGT, and bilirubin at initial phases of treatment possibly due to bile obstruction which subsided over time (after 5 weeks) without cessation of intervention [54]. In subacute and subchronic toxicity studies conducted on rats (fresh C. papaya leaf juice, up to $2000 \mathrm{mg} / \mathrm{kg}$ ) according to the Organization for Economic Cooperation and Development (OECD) Guidelines for Testing of Chemicals, although elevated liver enzymes were observed, no histopathological changes were detected in the liver postmortem [56, 57]. In a single-dose acute toxicity study of $C$. papaya leaf aqueous extract, no death, acute adverse events, and biochemical abnormalities were detected at doses up to $2000 \mathrm{mg} / \mathrm{kg}$ [55]. Among the major compounds identified in C. papaya leaf are rutin, carpaine, manghaslin, papain, and clitorin [56, 71]. Currently, there is little evidence available on the hepatotoxicity of these individual compounds. Among these, rutin has, in fact, demonstrated hepatoprotective properties possibly via antioxidant and anti-inflammatory effects $[72,73]$, while an in silico docking study predicted that carpaine has low-risk hepatotoxic potential [74]. The mechanism of hepatotoxicity of C. papaya leaf remains to be elucidated. In view of concerns on hepatotoxicity, C. papaya leaf consumption should be cautioned in patients with underlying hepatic impairment while safety in long-term consumption remains to be ascertained. Future clinical trials should also include assessments and detailed reports on liver function tests to further ensure its safety specific to the investigated formulation. Insufficient reporting on the effects of investigated C. papaya leaf formulations on serum liver enzymes was found to be one of the contributing factors of reporting bias in the randomised clinical trials included here.

Reproductive side effects have also been reported in animal studies $[53,58]$. At doses above $60 \mathrm{mg} / \mathrm{kg}$, air-dried C. papaya leaf decoction administered throughout the gestational period negatively impacted the length of gestation and fertility index, as well as litter size and birth weight of female rats [58]. Male reproductive toxicity of $C$. papaya leaf decoction (10 to $500 \mathrm{mg} / \mathrm{kg}, 14$ to 21 days), evidenced by impairment in all investigated andrological parameters including semen analysis, serum follicle stimulating hormone (FSH), luteinising hormone (LH), and testosterone levels, as well as degenerative changes of the seminiferous tubule epithelium, was observed in two animal studies $[53,58]$. As there are insufficient data on the effects of short-term consumption of $C$. papaya leaf on the reproductive system, pregnant women are often excluded from clinical trials; the risk of consumption during human pregnancy cannot be ruled out and should, therefore, be avoided.

4.1.3. Herb-Drug Interactions. In clinical trials, C. papaya leaf was commonly administered with routine supportive treatment of dengue fever which often includes antipyretics and antiemetics. No unfavourable outcomes were explicitly reported with short durations of coadministration with these drugs, though it was not within the trials' objectives to investigate herb-drug interactions $[6,34,36,37,39-41$, $43,48,49]$. In preclinical studies, C. papaya leaf 
demonstrated significant herb-drug interaction with several drugs including metformin, glimepiride, digoxin, ciprofloxacin, and artemisinin [60-65]. Herb-drug interaction investigations revealed complex interactions between $96 \%$ C. papaya leaf ethanolic extract and other oral hypoglycaemic agents (metformin and glimepiride) [60]. As a single intervention, C. papaya leaf reported hypoglycaemic activity $[75,76]$. When given in combination with metformin, 96\% C. papaya leaf ethanolic extract initially reduced metformin's hypoglycaemic effect at two hours but subsequently enhanced its effect at 24 hours. For coadministration with glimepiride, the same extract delayed the onset of hypoglycaemic effect but eventually enhanced it at 24 hours. The mechanism of interaction was not elucidated, but combined pharmacokinetic (reduced absorption) and pharmacodynamic interactions (differential effects seen with oral hypoglycaemic agents with different mechanisms of action) were proposed [60].

Differential interaction effects were also reported between two C. papaya leaf formulations with the antimalarial, artemisinin. When administered in combination with artemisinin, isobologram analysis shows subsynergism or additive antimalarial effects of $C$. papaya leaf decoction against Plasmodium falciparum [61, 65]. C. papaya leaf reported antimalarial properties as a single intervention $[65,77,78]$, which may contribute towards some pharmacodynamic additive effects, though the mechanisms remain unclear. On the other hand, C. papaya leaf crude aqueous extract demonstrated antagonistic antimalarial effects against artemisinin in Plasmodium-berghei-infected mice [62]. Antagonistic activities were thought to be attributable to the pharmacological properties of these two agents [62]. C. papaya leaf has reported antioxidant activities due to the presence of phenolic compounds [79] which may oppose the antimalarial activity of artemisinin achieved through freeradical production [80]. The exact factors that contributed towards such contrasting findings of herb-drug interaction between $C$. papaya leaf and artemisinin remain unclear. Still, these findings further strengthen the evidence on the presence of variable phytochemical composition in different formulations of the same plant, resulting in different activities [69].

An in vitro phamacokinetic interaction study reported that dried C. papaya leaf decoction of aqueous extract inhibits p-glycoprotein transport of digoxin in a dose-dependent manner, hence potentially impeding intestinal absorption and bioavailability of digoxin [63]. However, the mechanism and nature of inhibition were not investigated. C. papaya leaf aqueous extract, given 30 minutes prior to ciprofloxacin, also resulted in decreased absorption and shorter serum half-life of ciprofloxacin in rabbits [64]. As ciprofloxacin is well known to chelate with cations such as $\mathrm{Ca}^{2+}[81]$, reduced absorption of ciprofloxacin was thought to be partly due to binding with low levels of minerals and heavy metals present in the investigated formulation [64].

One of the most common pathways of herb-drug interaction is through the effect on cytochrome (CYP) enzymes, a major group of liver metabolising enzymes of many drugs [82]. At present, there is limited information on the effects of $C$. papaya leaf on these enzymes, though in silico prediction on individual phytochemical compounds present in C. papaya leaf have reported potential inhibitory effects [74]. Future studies on the effects of C. papaya leaf on various CYP enzymes are useful in improving the understanding of its safety profile and governance of its clinical administration.

4.2. Extrinsic Toxicity. No conclusive findings on extrinsic toxicity can be drawn as most of the required quality data to assess extrinsic toxicity were not sufficiently reported based on the CONSORT reporting checklist for herbal interventions, item No. 4 [29]. It was observed that adherence to recommended reporting guidelines was suboptimal in the included clinical papers of this review, similar to previous findings of systematic reviews assessing the reporting quality of herbal trials $[83,84]$. There is insufficient reporting on the chemical fingerprinting and qualitative evaluation of phytochemical composition or other foreign materials, e.g., pesticide in most randomised controlled and quasiexperimental trials. Only one paper reported that the heavy-metal levels of the investigated test item were within allowable limits [6].

Heavy-metal contamination from soil and the presence of pesticides in raw plants of herbs used in formulating the final herbal medicine product are important factors to consider when evaluating extrinsic toxicity [85]. It has been reported that heavy metals and pesticides are commonly detected in various plants and herbs [86, 87]. It is commonly understood that quality data specific to the investigated test item are required by regulatory authorities of several countries for approval of product registration and conducting clinical trials $[88,89]$. Therefore, this may explain our observation on the lack of reporting as test items may be assumed to be of sufficient quality as regulated by individual authorities. However, to allow for meaningful data pooling and analysis of future studies, there is still a need to improve awareness of the availability and compliance to such reporting standards for published articles, specific to herbal medicine trials [29].

4.3. Limitations. There are several limitations of this review. Firstly, only English articles were included. However, our paper took into account all previously published randomised controlled trials which were included in the two most recent systematic reviews on efficacy and safety of C. papaya leaf in dengue patients $[24,25]$, with additional published papers on other medical condition apart from dengue, as well as articles from grey literature. Hence, we still think that this review adequately represents the bulk of the available safety and herb-drug interaction evidence specific to C. papaya leaf consumption.

Quantitative analysis to pool incidence of reported adverse reactions was not possible in this review due to the lack of data on actual incidence of each adverse event in both treatment arms reported. Insufficient reporting on quantitative analysis on the phytochemical composition of an 
individual test item further contributed towards the difficulty in performing meaningful data comparison. Furthermore, as only three out of thirteen trials administered a placebo in the control group, there is a high risk for performance bias for such analysis. Lastly, this review was unable to critically evaluate the risk of extrinsic toxicity due to limited reporting on the quality of test items/herbal interventions investigated.

\section{Conclusions}

In conclusion, C. papaya leaf consumption in adults is generally safe for short-term use though cautioned in pregnancy and people with liver impairment. Gastrointestinal disturbances and rash are the most commonly reported side effects. The most frequent investigated formulation is leaf juice at doses of $2.5 \mathrm{~mL}$ in children to $150 \mathrm{~mL}$ in adults per day followed by standardised aqueous extract $(40 \%$ glycosides) tablets at $1100 \mathrm{mg}$ three times daily. C. papaya leaf has potential herb-drug interactions with oral hypoglycaemic agents, p-glycoprotein substrates, and antibiotics with cation chelating properties; hence, coadministration of these agents should be avoided. Postmarketing surveillance to monitor the safety of C. papaya leaf administration in the larger populations is warranted, with special focus recommended on hepatic side effects.

\section{Abbreviations}

$\begin{array}{ll}\text { ADR: } & \text { Adverse drug reaction } \\ \text { ALOX12: } & \text { Arachidonate 12-lipoxygenase } \\ \text { ALP: } & \text { Alkaline phosphatase } \\ \text { ALT: } & \text { Alanine transaminase } \\ \text { AST: } & \text { Aspartate transaminase } \\ \text { CONSORT: } & \text { Consolidated Standards of Reporting Trials } \\ \text { CYP: } & \text { Cytochrome } \\ \text { FSH: } & \text { Follicle stimulating hormone } \\ \text { GGT: } & \text { Gamma-glutamyl transferase } \\ \text { LH: } & \text { Luteinising hormone } \\ \text { LILACS: } & \text { Latin American and Caribbean Health } \\ \text { MADRAC: } & \text { Sciences Literature } \\ & \text { Committee } \\ \text { OECD: } & \text { Organization for Economic Cooperation and } \\ \text { PICO: } & \text { Development } \\ & \text { Population, Intervention, Comparison, and } \\ \text { PRISMA: } & \text { Outcomes } \\ & \text { Preferred Reporting Items for Systematic } \\ \text { PRISMA- } & \text { Reviews and Meta-Analyses } \\ \text { SCR: } & \begin{array}{l}\text { Preferred Reporting Items for Systematic } \\ \text { Reviews and Meta-Analyses Extension for }\end{array} \\ \text { WHO: } & \begin{array}{l}\text { Scoping Reviews } \\ \text { World Health Organization. }\end{array}\end{array}$

\section{Data Availability}

All data used to support the findings of this study are included within the article and supplementary information files.

\section{Conflicts of Interest}

The authors declare that there are no conflicts of interest regarding the publication of this paper.

\section{Acknowledgments}

The authors would like to thank the Director General of Health Malaysia, Deputy Director General of Health Malaysia (Research \& Technical Support), and Director of Institute for Medical Research, Head Centre of Herbal Medicine Research Centre, for their support and permission to publish this article. The authors would also like to extend their gratitude towards Dr. Azuana Ramli, Head of the Pharmacovigilance Section, Centre for Compliance and Quality Control, National Pharmaceutical Regulatory Agency, Ministry of Health, Malaysia, for providing information on ADR reports from the MADRAC database.

\section{Supplementary Materials}

S1 Table. Details of ongoing trials. S1 Appendix. Sample search strategy and keywords. S2 Appendix. Data extraction tables. S3 Appendix. PRISMA-ScR checklist. S4 Appendix. CONSORT checklist for herbal trials, item No. 4. (Supplementary Materials)

\section{References}

[1] G. Aravind, D. Bhowmik, S. Duraivel, and G. Harish, "Traditional and medicinal uses of Carica papaya," Journal of Medicinal Plants Studies, vol. 1, pp. 7-15, 2013.

[2] H. C. Ong, R. M. Zuki, and P. Milow, “Traditional knowledge of medicinal plants among the Malay villagers in Kampung Mak Kemas, Terengganu, Malaysia," Studies on Ethno-Medicine, vol. 5, no. 3, pp. 175-185, 2011.

[3] H. C. Ong and J. Norzalina, "Malay herbal medicine in Gemencheh, Negri Sembilan, Malaysia," Fitoterapia, vol. 70, no. 1, pp. 10-14, 1999.

[4] N. Sarala and S. Paknikar, "Papaya extract to treat dengue: a novel therapeutic option?" Annals of Medical and Health Sciences Research, vol. 4, no. 3, pp. 320-324, 2014.

[5] D. Sundarmurthy, R. Jayanthi, and L. Kuntegowdanahalli, "Effect of Carica papaya leaf extract on platelet count in chemotherapy-induced thrombocytopenic patients: a preliminary study," National Journal of Physiology, Pharmacy and Pharmacology, vol. 7, p. 1, 2017.

[6] S. Subenthiran, T. C. Choon, K. C. Cheong et al., "Carica papaya leaves juice significantly accelerates the rate of increase in platelet count among patients with Dengue fever and Dengue haemorrhagic fever," Evidence Based Complementary and Alternative Medicine, vol. 2013, Article ID 616737, 2013.

[7] D. J. Gubler, "Dengue and Dengue hemorrhagic fever," Clinical Microbiology Reviews, vol. 11, no. 3, pp. 480-496, 1998.

[8] V. Anjum, P. Arora, S. H. Ansari, A. K. Najmi, and S. Ahmad, "Antithrombocytopenic and immunomodulatory potential of metabolically characterized aqueous extract of Carica papaya leaves," Pharmaceutical Biology, vol. 55, no. 1, pp. 2043-2056, 2017.

[9] S. Chinnappan, V. S. R. K. Tamilarasu, U. M. Krishnan, A. K. B. Pillai, and S. Rajendiran, "Inhibition of platelet 
aggregation by the leaf extract of Carica papaya during Dengue infection: an in vitro study," Viral Immunology, vol. 29, no. 3, pp. 164-168, 2016.

[10] N. Sharma, K. P. Mishra, S. Chanda et al., "Evaluation of antidengue activity of Carica papaya aqueous leaf extract and its role in platelet augmentation," Archives of Virology, vol. 164, no. 4, pp. 1095-1110, 2019.

[11] K. Sobia, M. Javaid, M. Ahmad et al., "Assessments of phytochemicals and hypoglycemic activity of leaves extratcs of Carica papaya in diabetic mice," International Journal of Pharmaceutical Sciences, vol. 7, pp. 1000-1008, 2016.

[12] V. Sheneni and P. Idakwoji, "In-vivo biological effects of Carica papaya leaf- extracts on P-407-induced hyperlipidemia in albino Wistar rats," Journal of Medical Sciences, vol. 6, pp. 1243-1249, 2018.

[13] M. Indran, A. A. Mahmood, and U. R. Kuppusamy, "Protective effect of Carica papaya L leaf extract against alcohol induced acute gastric damage and blood oxidative stress in rats," West Indian Medical Journal, vol. 57, no. 4, pp. 323-326, 2008.

[14] C. Baskaran, V. R. Bai, S. Velu, and K. Kumaran, "The efficacy of Carica papaya leaf extract on some bacterial and a fungal strain by well diffusion method," Asian Pacific Journal of Tropical Disease, vol. 2, pp. S658-S662, 2012.

[15] W.-C. Teng, W. Chan, R. Suwanarusk et al., "In vitro antimalarial evaluations and cytotoxicity investigations of Carica papaya leaves and carpaine," Natural Product Communications, vol. 14, no. 1, p. 1934578X1901400110, 2019.

[16] M. Abdulla, K. Sidik, and S. Ismail, "Wound healing activity of Carica papaya L. aqueous leaf extract in rats," International Journal of Molecular Medicine and Advance Sciences, vol. 1, 2005.

[17] I. E. Juárez-Rojop, C. A. Tovilla-Zárate, D. E. AguilarDomínguez et al., "Phytochemical screening and hypoglycemic activity of Carica papaya leaf in streptozotocin-induced diabetic rats," Revista Brasileira de Farmacognosia, vol. 24, pp. 341-347, 2014.

[18] N. Gogna, N. Hamid, and K. Dorai, "Metabolomic profiling of the phytomedicinal constituents of Carica papaya L. leaves and seeds by $1 \mathrm{H}$ NMR spectroscopy and multivariate statistical analysis," Journal of Pharmaceutical and Biomedical Analysis, vol. 115, pp. 74-85, 2015.

[19] A. Canini, D. Alesiani, G. D'Arcangelo, and P. Tagliatesta, "Gas chromatography-mass spectrometry analysis of phenolic compounds from Carica papaya L. leaf," Journal of Food Composition and Analysis, vol. 20, no. 7, pp. 584-590, 2007.

[20] V. Zunjar, R. P. Dash, M. Jivrajani, B. Trivedi, and M. Nivsarkar, "Antithrombocytopenic activity of carpaine and alkaloidal extract of Carica papaya Linn. leaves in busulfan induced thrombocytopenic Wistar rats," Journal of Ethnopharmacology, vol. 181, pp. 20-25, 2016.

[21] World Health Organisation (WHO), Global Report on Traditional and Complementary Medicine 2019, WHO, Geneva, Switzerland, 2019.

[22] C. Jayasinghe, Y. De Mel, S. Perera, and P. Ratnaweera, "Novel insights of toxicological evaluation of herbal medicine: human-based toxicological assays," AJPP, vol. 3, pp. 41-49, 2017.

[23] S. P. Borse, D. P. Singh, and M. Nivsarkar, "Understanding the relevance of herb-drug interaction studies with special focus on interplays: a prerequisite for integrative medicine," Porto Biomedical Journal, vol. 4, no. 2, p. e15, 2019.

[24] J. Charan, D. Saxena, J. P. Goyal, and S. Yasobant, "Efficacy and safety of Carica papaya leaf extract in the dengue: a systematic review and meta-analysis," International Journal of
Applied And Basic Medical Research, vol. 6, no. 4, pp. 249-254, 2016.

[25] S. Rajapakse, N. L. De Silva, P. Weeratunga, C. Rodrigo, C. Sigera, and S. D. Fernando, "Carica papaya extract in Dengue: a systematic review and meta-analysis," $B M C$ Complementary and Alternative Medicine, vol. 19, no. 1, p. 265, 2019.

[26] H. Arksey and L. O’Malley, “Scoping studies: towards a methodological framework," International Journal of Social Research Methodology, vol. 8, no. 1, pp. 19-32, 2005.

[27] D. Levac, H. Colquhoun, and K. K. O’Brien, “Scoping studies: advancing the methodology," Implementation Science, vol. 5, no. 1, p. 69, 2010.

[28] National Institute for Health Research, PROSPERO: International Prospective Register of Systematic Reviews, National Institute for Health Research, Bethesda, MD, USA, 2016, https://www.crd.york.ac.uk/prospero/\#aboutpage.

[29] J. J. Gagnier, H. Boon, P. Rochon, D. Moher, J. Barnes, and C. Bombardier, "Recommendations for reporting randomized controlled trials of herbal interventions: explanation and elaboration," Journal of Clinical Epidemiology, vol. 59, no. 11, pp. 1134-1149, 2006.

[30] Bahagian Dasar dan Perancangan Strategik Farmasi Kementerian Kesihatan Malaysia, "Garis panduan menjalankan penyelidikan di bawah program perkhidmatan farmasi kementerian Kesihatan Malaysia," 2018.

[31] A. C. Tricco, E. Lillie, W. Zarin et al., "PRISMA extension for scoping reviews (PRISMA-ScR): checklist and explanation," Annals of Internal Medicine, vol. 169, no. 7, pp. 467-473, 2018.

[32] S. Hettige, "Salutary effects of Carica papaya leaf extract in Dengue fever patients-a pilot study," Sri Lankan Family Physician, vol. 29, no. 1, pp. 17-19, 2008.

[33] N. Ahmad, H. Fazal, M. Ayaz, B. H. Abbasi, I. Mohammad, and L. Fazal, "Dengue fever treatment with Carica papaya leaves extracts," Asian Pacific Journal of Tropical Biomedicine, vol. 1, no. 4, pp. 330-333, 2011.

[34] M. Z. K. Assir, H. Mansoor, T. Waseem, H. Ahmed, S. Bukhari, and J. Akram, "Effect of papaya leaf extract on platelet count in Dengue fever: a randomized controlled trial (PLEAD Trial)," International Journal of Infectious Diseases, vol. 16, p. e473, 2012.

[35] C. P. Kala, "Leaf juice of Carica papaya L.: a remedy of Dengue fever," Medicinal \& Aromatic Plants, vol. 1, pp. 1-2, 2012.

[36] F. Yunita, E. Hanani, and J. Kristianto, "The effect of Carica papaya L. leaves extract capsules on platelets count and hematocrit level in Dengue fever patient," IJMAP, vol. 2, pp. 573-578, 2016.

[37] A. Gowda, N. V. Kumar, P. N. Kasture, and K. Nagabhushan, "A pilot study to evaluate the effectiveness of Carica papaya leaf extract in increasing the platelet count in cases of Dengue with thrombocytopenia," Indian Medical Gazette, vol. 149, pp. 1-8, 2015.

[38] O. Siddique, A. Sundus, and M. F. Ibrahim, "Effects of papaya leaves on thrombocyte counts in Dengue--a case report," Journal of Pakistan Medical Association, vol. 64, no. 3, pp. 364-366, 2014.

[39] G. Abhishek, T. Vinod, S. K. Malik, S. K. Virmani, and S. Saurabh, "Efficacy of Carica papaya leaf extract in treating thrombocytopenia in cases of Dengue," Journal of Advances in Health and Medical Sciences, vol. 7, pp. 1-4, 2015.

[40] A. K. Gadhwal, B. S. Ankit, C. Chahar, P. Tantia, P. Sirohi, and R. P. Agrawal, "Effect of Carica papaya leaf extract capsule on platelet count in patients of Dengue fever with 
thrombocytopenia," Journal of Association of Physicians of India, vol. 64, no. 6, pp. 22-26, 2016.

[41] P. N. Kasture, K. H. Nagabhushan, and A. Kumar, "A multicentric, double-blind, placebo-controlled, randomized, prospective study to evaluate the efficacy and safety of Carica papaya leaf extract, as empirical therapy for thrombocytopenia associated with Dengue fever," Journal of Association of Physicians of India, vol. 64, no. 6, pp. 15-20, 2016.

[42] A. Singhai, V. Juneja, S. Abbas, and R. K. Jha, "The effect of Carica papaya leaves extract capsules on platelets count and hematocrit levels in acute febrile illness with thrombocytopenia patient," International Journal of Medical Research \& Health Sciences, vol. 5, pp. 254-257, 2016.

[43] V. Adarsh, K. Doddamane, and V. D. Kumar, "Role of Carica papaya leaf product in improving the platelet count in patients with Dengue fever," International Journal of Research in Medicine, vol. 6, no. 2, pp. 63-68, 2017.

[44] S. M. Hussain, M. Sohrab, A. K. Al-Mahmood, M. Shuayb, M. Al-Mansur, and C. Hasan, "Clinical use of Carica papaya leaf extract in chemotherapy induced thrombocytopaenia," International Journal of Clinical and Experimental Medicine, vol. 10, pp. 3752-3756, 2017.

[45] L. T. Rahmat and L. E. Damon, "The use of natural health products especially papaya leaf extract and dandelion root extract in previously untreated chronic myelomonocytic leukemia," Case Reports in Hematology, vol. 2018, Article ID 7267920, , 2018.

[46] K. Hampilos, J. Corn, W. Hodsdon et al., "Effect of Carica papaya leaf extract on platelet count in chronic immune thrombocytopenic purpura: a case series," Integrative Medicine (Encinitas), vol. 18, no. 5, pp. 30-35, 2019.

[47] A. Pandita, N. Mishra, G. Gupta, and R. Singh, "Use of papaya leaf extract in neonatal thrombocytopenia," Clinical Case Reports, vol. 7, no. 3, pp. 497-499, 2019.

[48] B. K. Srikanth, L. Reddy, S. Biradar, M. Shamanna, D. D. Mariguddi, and M. Krishnakumar, "An open-label, randomized prospective study to evaluate the efficacy and safety of Carica papaya leaf extract for thrombocytopenia associated with Dengue fever in pediatric subjects," Pediatric Health, Medicine and Therapeutics, vol. 10, pp. 5-11, 2019.

[49] D. T. Sathyapalan, A. Padmanabhan, M. Moni et al., "Efficacy \& safety of Carica papaya leaf extract (CPLE) in severe thrombocytopenia $(\leq 30,000 / \mu \mathrm{l})$ in adult dengue-results of a pilot study," PLoS One, vol. 15, no. 2, Article ID e0228699, 2020.

[50] P. Sreelatha and W. Jose, "Efficacy of Carica papaya leaf extract in reducing treatment-delay secondary to chemotherapy induced thrombocytopenia," Journal of Clinical and Diagnostic Research, vol. 14, pp. XC09-XC12, 2020.

[51] H. S. Lei, A. F. Ab Rahman, and A. H. Syed M Haq, "Adverse drug reaction reports in Malaysia: comparison of causality assessment," Malaysian Journal of Pharmaceutical Sciences, vol. 5, no. 1, pp. 7-17, 2007.

[52] Micro labs limited Caripill: science behind caripill http:// webcache.googleusercontent.com/search?q=cache:447D6KM iALAJ:www.caripillmicro.com/science-behind-caripill.php+ $\& c d=1 \& h \mathrm{l}=$ en $\& \mathrm{ct}=\mathrm{clnk} \& \mathrm{gl}=$ my\&client $=\mathrm{ms}$-android-huaweirev1.

[53] O. Akinloye Olanrewaju and O. M. Morayo, "Evaluation of andrological indices and testicular histology following chronic administration of aqueous extract of Carica papaya leaf in Wistar rat," African Journal of. Pharmacy and Pharmacology, vol. 4, 2010.
[54] A. A. Omonkhua and I. O. Onoagbe, "Long-term hepatotoxicity and hypoglycaemic study of aqueous extracts of Carica papaya leaves on normal rabbits," Global Journal of Pure and Applied Sciences, vol. 17, no. 3, pp. 241-247, 2011.

[55] S. Z. Halim, N. Abdullah, A. Afzan, B. Abd Rashid, I. Jantan, and Z. Ismail, "Acute toxicity study of Carica papaya leaf extract in Sprague Dawley rats," Journal of Medicinal Plants Research, vol. 5, pp. 1867-1872, 2011.

[56] A. Afzan, N. R. Abdullah, S. Z. Halim et al., "Repeated dose 28-days oral toxicity study of Carica papaya L. leaf extract in Sprague Dawley rats," Molecules, vol. 17, no. 4, pp. 4326-4342, 2012.

[57] Z. Ismail, S. Z. Halim, N. R. Abdullah, A. Afzan, B. A. Abdul Rashid, and I. Jantan, "Safety evaluation of oral toxicity of Carica papaya Linn. leaves: a subchronic toxicity study in Sprague Dawley rats," Evidence Based Complementary and Alternative Medicine, vol. 2014, Article ID 741470, 2014.

[58] C. Ansah, J. A. Appiah, K. Mensah, and P. Mante, "Aqueous leaf extract of Carica papaya (Caricaceae) Linn. causes liver injury and reduced fertility in rats," International Journal of Pharmacy and Pharmaceutical Sciences, vol. 8, pp. 261-265, 2016.

[59] N. W. Nghonjuyi, C. K. Tiambo, G. S. Taïwe et al., "Acute and sub-chronic toxicity studies of three plants used in Cameroonian ethnoveterinary medicine: Aloe vera (L.) Burm. f. (Xanthorrhoeaceae) leaves, Carica papaya L. (Caricaceae) seeds or leaves, and Mimosa pudica L. (Fabaceae) leaves in Kabir chicks," Journal of Ethnopharmacology, vol. 178, pp. 40-49, 2015.

[60] T. Fakeye, T. Oladipupo, O. Showande, and Y. Ogunremi, "Effects of coadministration of extract of Carica papaya Linn (family Cariaceae) on activity of two oral hypoglycemic agents," Tropical Journal of Pharmaceutical Research, vol. 61 page, 2007.

[61] A. R. Sannella, A. Karioti, F. F. Vincieri et al., "Antiplasmodial activity of papaya leaf decoction and its synergistic effects in combination with artemisinin," Planta Medica, vol. 75, no. 9, p. PD37, 2020.

[62] L. O. Onaku, A. A. Attama, V. C. Okore, A. Y. Tijani, A. A. Ngene, and C. O. Esimone, "Antagonistic antimalarial properties of pawpaw leaf aqueous extract in combination with artesunic acid in Plasmodium berghei-infected mice," Journal of Vector Borne Diseases, vol. 48, no. 2, pp. 96-100, 2011.

[63] E. F. Oga, S. Sekine, Y. Shitara, and T. Horie, "P-glycoprotein mediated efflux in Caco-2 cell monolayers: the influence of herbals on digoxin transport," Journal of Ethnopharmacology, vol. 144, no. 3, pp. 612-617, 2012.

[64] G. Ukpo, M. Owolabi, N. Imaga, O. Olaleye, and A. Ejiroghene, "Effect of Carica papaya (Linn) aqueous leaf extract on pharmacokinetic profile of ciprofloxacin in rabbits," Tropical Journal of Pharmaceutical Research, vol. 16, p. 127, 2017.

[65] A. R. Sannella, A. Karioti, S. Orsini et al., "Leaf decoction of Carica papaya combined with artesunate prevents recrudescence in Plasmodium berghei-infected Mmice," Planta Medica, vol. 85, no. 11-12, pp. 934-940, 2019.

[66] E. E. Ooi and D. J. Gubler, "Dengue in Southeast Asia: epidemiological characteristics and strategic challenges in disease prevention," Cadernos de Saúde Pública, vol. 25, no. Suppl 1, pp. S115-S124, 2009.

[67] A. Wilder-Smith and P. Rupali, "Estimating the dengue burden in India," Lancet Global Health, vol. 7, no. 8, pp. e988-e989, 2019. 
[68] W. Liu, D. Yin, N. Li et al., "Influence of environmental factors on the active substance production and antioxidant activity in Potentilla fruticosa L. and its quality assessment," Scientific Reports, vol. 6, no. 1, p. 28591, 2020.

[69] N. Asghar, S. A. Naqvi, Z. Hussain et al., "Compositional difference in antioxidant and antibacterial activity of all parts of the Carica papaya using different solvents," Chemistry Central Journal, vol. 10, p. 5, 2016.

[70] W. Liu, J. Liu, D. Yin, and X. Zhao, "Influence of ecological factors on the production of active substances in the anticancer plant Sinopodophyllum hexandrum (Royle) T.S. Ying," PLoS One, vol. 10, no. 4, Article ID e0122981, 2015.

[71] M. Tigist, B. Getnet, K. Beza et al., "Extraction and purification of papain enzyme from papaya leaf and the phytochemical components of the leaf," BTI, vol. 9, no. 8, pp. 176-184, 2021.

[72] M. K. Reddy, A. G. Reddy, B. K. Kumar, D. Madhuri, G. Boobalan, and M. A. Reddy, "Protective effect of rutin in comparison to silymarin against induced hepatotoxicity in rats," Veterinary World, vol. 10, no. 1, pp. 74-80, 2017.

[73] S. D. AlSharari, S. S. Al-Rejaie, H. M. Abuohashish, M. M. Ahmed, and M. M. Hafez, "Rutin attenuates hepatotoxicity in high-cholesterol-diet-fed rats," Oxidative Medicine and Cellular Longevity, vol. 2016, p. 5436745, 2016.

[74] R. Narayanaswamy, L. Kw, and N. Me, "Molecular docking analysis of Carica papaya Linn constituents as antiviral agent," International Food Research Journal, vol. 24, pp. 1819-1825, 2017.

[75] P. H. Miranda-Osorio, A. E. Castell-Rodríguez, J. VargasMancilla et al., "Protective action of Carica papaya on $\beta$-Cells in streptozotocin-induced diabetic rats," International Journal of Environmental Research and Public Health, vol. 13, no. 5, p. 446, 2016.

[76] C. Nissa, M. Kartasurya, and B. Rahmawati, "Effects of chlorophyll in papaya leaves on superoxide dismutation and blood glucose level of diabetic rats," Makara Journal of Health Research, vol. 19, 2016.

[77] K. Kovendan, K. Murugan, D. C. Panneerselvam et al., "Antimalarial activity of Carica papaya (Family: caricaceae) leaf extract against Plasmodium falciparum," Asian Pacific Journal of Tropical Disease, vol. 2, pp. S306-S311, 2012.

[78] O. Okpe, N. Habila, J. Ikwebe, V. A. Upev, S. I. R. Okoduwa, and O. T. Isaac, "Antimalarial potential of Carica papaya and Vernonia amygdalina in mice infected with Plasmodium berghei," Journal of Tropical Medicine, vol. 2016, p. 8738972, 2016.

[79] S. De Mandal, R. Lalmawizuala, V. Mathipi, N. Dr, and E. Lalnunmawii, "An investigation of the antioxidant property of Carica papaya leaf extracts from Mizoram, Northeast India," RRJoB, vol. 4, pp. 43-46, 2015.

[80] S. R. Meshnick, "Artemisinin: mechanisms of action, resistance and toxicity," International Journal for Parasitology, vol. 32, no. 13, pp. 1655-1660, 2002.

[81] Z. H. Chohan, C. T. Supuran, and A. Scozzafava, "Metal binding and antibacterial activity of ciprofloxacin complexes," Journal of Enzyme Inhibition and Medicinal, vol. 20, no. 3, pp. 303-307, 2005.

[82] T. Lynch and A. Price, "The effect of cytochrome P450 metabolism on drug response, interactions, and adverse effects," AAFP, vol. 76, pp. 391-396, 2007.

[83] K. Naumann, "A quantitative assessment of the reporting quality of herbal medicine research: the road to improvement," Journal of Alternative and Complementary Medicine, vol. 242 pages, 2018.
[84] X. Pan, M. A. Lopez-Olivo, J. Song, G. Pratt, and M. E. SuarezAlmazor, "Systematic review of the methodological quality of controlled trials evaluating Chinese herbal medicine in patients with rheumatoid arthritis," BMJ Open, vol. 7, no. 3, Article ID e013242, 2017.

[85] N. S. Shaban, K. A. Abdou, and N. E.-H. Y. Hassan, "Impact of toxic heavy metals and pesticide residues in herbal products," BJBAS, vol. 5, no. 1, pp. 102-106, 2016.

[86] V. Kumar, A. Sharma, G. Dhunna, A. Chawla, R. Bhardwaj, and A. Thukral, "A tabulated review on distribution of heavy metals in various plants," Environmental Science and Pollution Research, vol. 24, pp. 2210-2260, 2016.

[87] E. S. J. Harris, S. Cao, B. A. Littlefield et al., "Heavy metal and pesticide content in commonly prescribed individual raw Chinese herbal medicines," Science of the Total Environment, vol. 409, no. 20, pp. 4297-4305, 2011.

[88] S. Sharma, "Current status of herbal product: regulatory overview," Journal of Pharmacy \& Bioallied Sciences, vol. 7, no. 4, pp. 293-296, 2015.

[89] A. Parveen, B. Parveen, R. Parveen, and S. Ahmad, "Challenges and guidelines for clinical trial of herbal drugs," Journal of Pharmacy \& Bioallied Sciences, vol. 7, no. 4, pp. 329-333, 2015. 